Printed in the United States of America

Avallable from

National Technical Information Service

U S Department of Commerce

5285 Port Royal Road

Springfield, VA 22161

NTIS Price Codes Printed Copy A05

Microfiche A01

\section{DISCLAIMER}

This book was prepared as an account of work sponsored by an agency of the United States Government Netther the United States Government nor any agency thereof. nor any of their employees, makes any warranty, express or implied, or assumes any legal liability or responsibility for the accuracy, completeness, or usefulness of any information, apparatus, product or process disclosed, or represents that its use would not infringe privately owned rights References herein to any specific commercial product, process, or service by trade name, trademark, manufacturer, or otherwise, does not necessarily constitute or imply its endorsement, recommendation, or favoring by the United States Government or any agency thereof The views and opinions of authors expressed herein do not necessarily state or reflect those of the United States Government or any agency thereof 


\section{DISCLAIMER}

This report was prepared as an account of work sponsored by an agency of the United States Government. Neither the United States Government nor any agency Thereof, nor any of their employees, makes any warranty, express or implied, or assumes any legal liability or responsibility for the accuracy, completeness, or usefulness of any information, apparatus, product, or process disclosed, or represents that its use would not infringe privately owned rights. Reference herein to any specific commercial product, process, or service by trade name, trademark, manufacturer, or otherwise does not necessarily constitute or imply its endorsement, recommendation, or favoring by the United States Government or any agency thereof. The views and opinions of authors expressed herein do not necessarily state or reflect those of the United States Government or any agency thereof. 


\section{DISCLAIMER}

Portions of this document may be illegible in electronic image products. Images are produced from the best available original document. 


\title{
THREE MILE ISLAND UNIT-2 CORE STATUS SUMMARY: A BASIS FOR TOOL DEVELOPMENT FOR REACTOR DISASSEMBLY AND DEFUELING
}

\author{
Douglas W. Croucher
}

Published May 1981

EG\&G Idaho, Inc. Idaho Falls, Idaho 83415

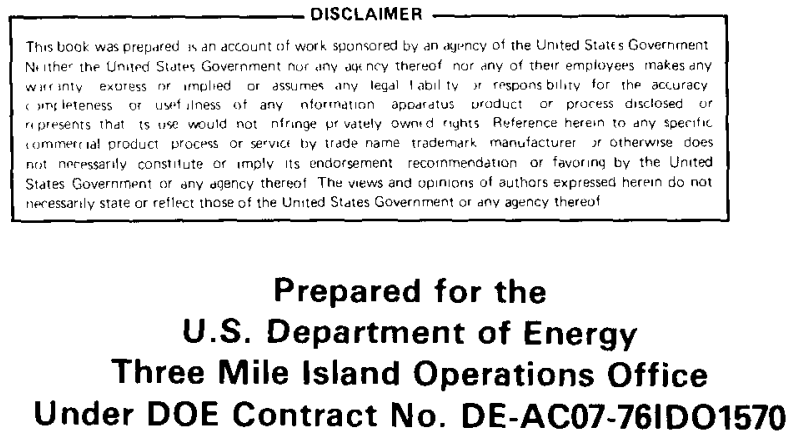


- 


\section{ACKNOWLEDGMENTS}

Appreciation is expressed to Dr. R. J. Loyd for his helpful discussions and review of this report.

This work was supported by the U.S. Department of Energy, Assistant Secretary for Nuclear Energy, Office of Energy Research, under DOE Contract No. DE-AC07-76ID01570. 
The accident at Three Mile Island Unit-2 (TMI-2) on March 28, 1979 caused extensive damage to the core. A variety of analyses were perforined using three general approaches to determine the extent of core damage. First, thermal-hydraulic events were reconstructed using available data, thermal-hydraulic principles, and computer analyses. Second, determinations of the hydrogen generated yielded estimates of the amount of zircaloy oxidized and embrittled. Third, the type and quantity of fission products released during the accident were used to estimate the location of core damage and the fuel temperatures which were achieved. Uncertainties exist in each type of determination due to the equivocal nature of the data. Thus, the purpose of this paper is to review and summarize the core damage assessments which have been made, identify the minimum and inaximum bounds of damage, and establish a "reference" description for the current status of the core. The different degrees of damage present in the reference core will be considered during development of contingency tooling and procedures for inspection, sample acquisition, and defueling of the core.

From reconstruction of the thermal-hydraulic events, it was concluded that the core remained covered up to 100 minutes into the accident and that most of the damage occurred during the period from 100 to 210 minutes when the core is thought to have been uncovered. Damage to the core is a strong function of the time-dependent steam-water mixture level in the core which was greatly affected by the net makeup flow during this period. Cladding reached temperatures between $1030 \mathrm{~K}\left(1395^{\circ} \mathrm{F}\right)$ and $1150 \mathrm{~K}\left(1610^{\circ} \mathrm{F}\right)$ and fajled by ballooning between 137 and 142 minutes. The cladding continued to increase in temperature, becoming oxidized and embrittled. The fuel reached peak temperatures varying between $2000 \mathrm{~K}\left(3140^{\circ} \mathrm{F}\right)$ and $2900 \mathrm{~K}$ $\left(4760^{\circ} \mathrm{F}\right)$. At temperatures greater than $2175 \mathrm{~K}\left(3455^{\circ} \mathrm{F}\right)$, uranium dioxide fuel pellets in contact with molten cladding could nave been dissolved by the zircaloy, forming a liquid phase of zirconium-uranium-oxygen termed "liquified fuel." The temperatures achieved are also high enough to melt 
Inconel spacer grids, stainless steel core components and the silver-indium-cadmium poison material in the control rods. Estimated temperatures of the upper plenum structure range between $1500 \mathrm{~K}\left(2240^{\circ} \mathrm{F}\right)$ and $1800 \mathrm{~K}\left(2780^{\circ} \mathrm{F}\right)$, high enough to suggest that melting of control rod guide tube brazements and stainless steel components may have occurred. At 174 minutes, a sudden influx of water to the core is expected to have rapidly quenched the embrittled cladding and hot fuel, fracturing the fuel rods and forming a debris bed in the upper region of the core. Additional core damage, probably core slumping and densification of the debris bed, apparently occurred at about 225 minutes. Postaccident core flow resistance measurements indicated an effective core flow area blockage of approximately $90 \%$. Since the peripheral fuel assemblies make up more than $20 \%$ of the core flow area, some blockage is expected at the periphery of the core.

Analyses of the hydrogen produced yielded estimates of the amount of zircaloy oxidized. Although oxidation of fuel and other core components could also generate hydrogen, the expected amount is small compared to that from oxidation of zircaloy. Estimates were based on the hydrogen and oxygen content of several postaccident containment building air samples, the pressure increase in the containment building signifying the amount of hydrogen burned, and estimates of the hydrogen present in the primary system, both free and in solution. About $50 \%$ of the zircaloy in the active core region is estimated to have been oxidized.

The assessment of core damage based on analyses of fission product release is not as precise as the first two methods, but it generally is confirmatory. Measured isotopic ratios of uranium and plutonium in the reactor building sump indicate that the central region of core, and perhaps the whole core, was uniformly damaged. The estimates of temperature based on fission products found in the coolant vary greatly, from gross core average temperatures below $2000 \mathrm{~K}\left(3140^{\circ} \mathrm{F}\right)$ to about $40 \%$ of the fuel greater than $2675 \mathrm{~K}\left(4355^{\circ} \mathrm{F}\right)$. There is general agreement, however, that the fue 1 remained below the melting point of $\mathrm{UO}_{2}$ because very little strontium, tellurium, and ruthenium were present. 
Factors of primary interest during reactor disassembly and removal of the core are the condition of the upper plenum, the amount of cladding oxidized, the presence of once molten materials such as liquified fuel and control rods, and the condition of the instrument and guide tubes. Some components of the upper plenum structure may have melted or fused together during the course of the accident necessitating the development of tooling and procedures for this contingency. It is evident that a bed of fragmented fuel and cladding has formed, perhaps extending to the core periphery. A few of the upper plenum components may rest on top of the debris. The amount of cladding oxidized, approximately $50 \%$, is indicative of the fraction of the core which is brittle or fragmented. The presence of liquified fuel, or any once molten material, is enough to ensure that some areas of the debris will be fused together and that separation techniques and tools must be designed accordingly. The total weight of potential debris and embrittled cladding is 64,000 to $83,000 \mathrm{~kg}(140,000$ to 184,000 1b). 


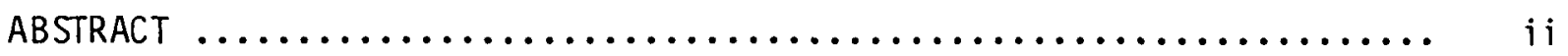

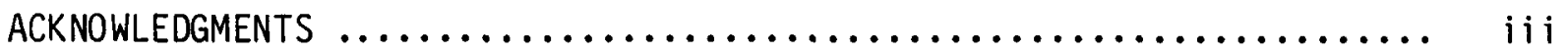

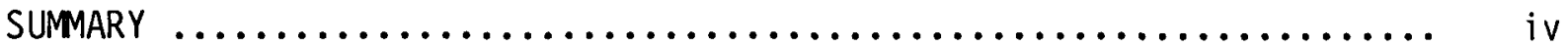

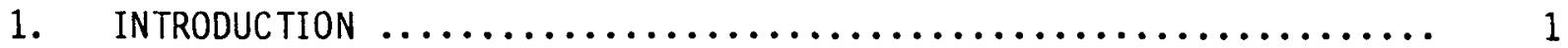

2. THERMAL-HYDRAULIC EVENTS $\ldots \ldots \ldots \ldots \ldots \ldots \ldots \ldots \ldots \ldots \ldots \ldots \ldots \ldots \ldots \ldots \ldots \ldots$

2.1 Transient Water-Steam Mixture Level ................. 4

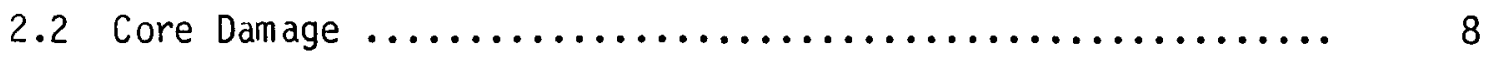

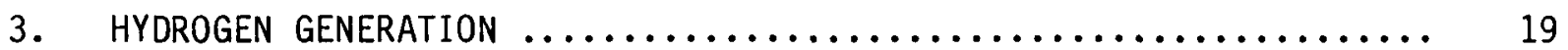

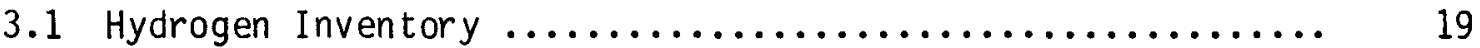

3.2 Computer Code Calculations ........................ 24

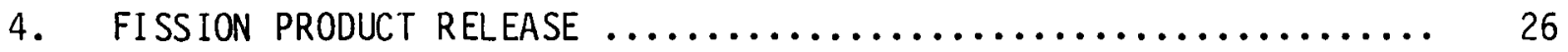

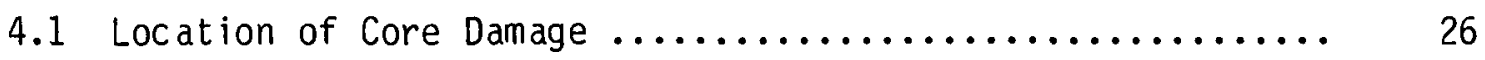

4.2 Fuel Temperatures $\ldots \ldots \ldots \ldots \ldots \ldots \ldots \ldots \ldots \ldots \ldots \ldots . \ldots \ldots$

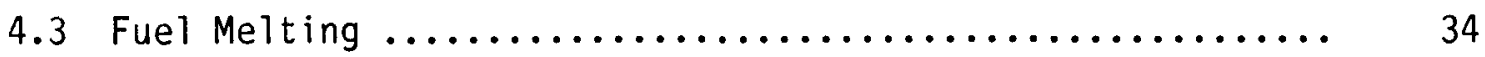

4.4 Particle Size Distribution ........................ 34

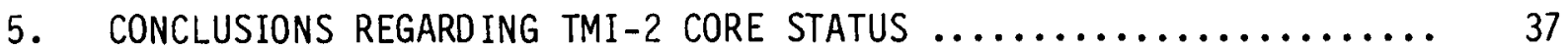

5.1 Damage Limits and Reference Core $\ldots \ldots \ldots \ldots \ldots \ldots \ldots \ldots . . . .6$

5.2 Tooling Development for Defueling $\ldots \ldots \ldots \ldots \ldots \ldots \ldots \ldots .43$

5.3 Conclusions $\ldots \ldots \ldots \ldots \ldots \ldots \ldots \ldots \ldots \ldots \ldots \ldots \ldots \ldots \ldots \ldots \ldots \ldots \ldots, 44$

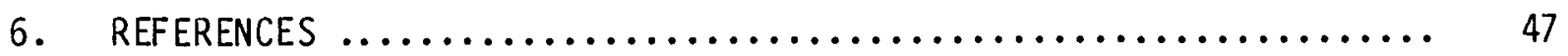

APPENDIX A TMI-2 CORE DESIGN PARAMETERS $\ldots \ldots \ldots \ldots \ldots \ldots \ldots \ldots \ldots . . \ldots \ldots$

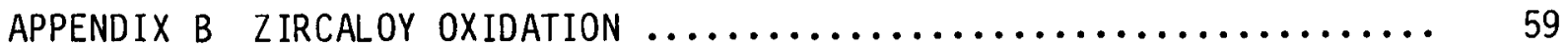

APPENDIX C ZIRCALOY INVENTORY AND DISTRIBUTION IN TMI-2 $\ldots \ldots \ldots \ldots .63$

APPENDIX D CONSTRUCTION OF CORE DAMAGE LIMIT ILLUSTRATIONS $\ldots \ldots \ldots \ldots 67$ 


\section{FIGURES}

1. Water-steam and core-mixture levels during uncovery from

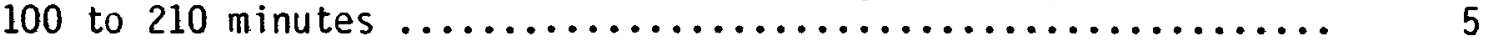

2. In-core instrumentation position $\ldots \ldots \ldots \ldots \ldots \ldots \ldots \ldots \ldots \ldots \ldots$

3. A top view of reactor core, illustrating location of

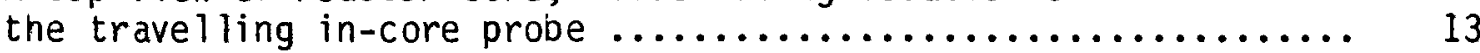

4. Pressure versus time in the reactor building after

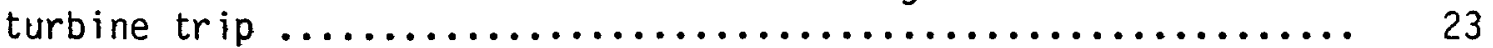

5. Particle size distributions from several types of tests $\ldots \ldots \ldots$

6. Regional average oxidation and estimated minimum damage

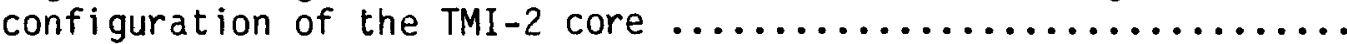

7. Regional average oxidation and reference configuration

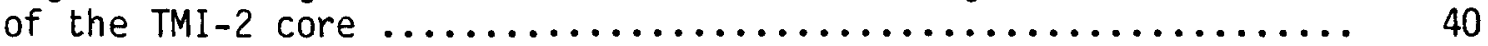

8. Regional average oxidation and est imated maximum damage configuration of the TMI-2 core

TABLES

1. Variation in Estimated Net Inlet Flow Rates Between 100

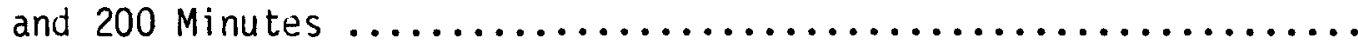

2. Sumary of Core Damage Estimates Based on Reconstruction

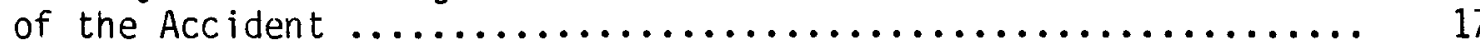

3. Hydrogen Inventory and Zircaloy 0xidized ................. 20

4. Containment Atmosphere Samples, March 31, 1979 at

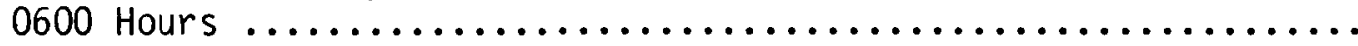

5. Fission Products in the Reactor Coolant from Samples Taken on March 29 and April 10, 1979

6. Radioactivity of Gas Sample from Containment Building

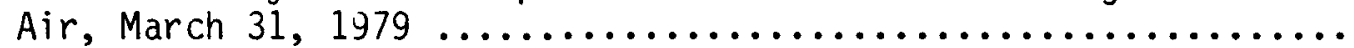

7. Comparison of Calculated and Observed Isotopic

Ratios of Uranium and Plutonium ....................... 30

8. Volatility Groupings of Fission Product Isotopes ............ 31

9. Sumary of Fission Product Release Fractions .............. 32

10. Sumary of Damage Estimates $\ldots \ldots \ldots \ldots \ldots \ldots \ldots \ldots \ldots \ldots \ldots \ldots$

11. Summary of Potential Range of Core Conditions to be Used for Planning of Contingency Tooling 
A-1. Fuel Assembly Components, Materials and Dimensions ......... 53

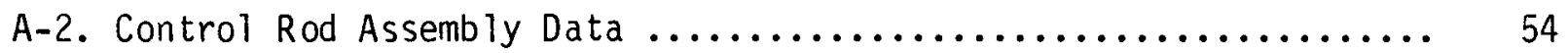

A-3. Axial Power Shaping Rod Assembly Data .................. 54

A-4. Burnable Poison Rod Assembly Data .................... 55

A-5. Orifice Rod Assembly Data ........................ 55

A-6. Core Design Data ..................................... 56

A-7. Melting Points of Core Materials ................... 57 
$\bullet$ 


\section{INTRODUCTION}

Following the accident at the Three Mile Island Unit-2 (TMI-2) Nuclear Power Station on March 28, 1979, examination planning groups were formed to make recommendations for core damage assessment and core removal, and for fuel experiments and examination. These are Planning Groups 7.2 and 7.4, respectively. In their recommendations contained in the GEND Planning

Report, 1 each group recognized the need to thoroughly understand the nature of the present configuration of the TMI-2 core and related components. The planning reports addressed several types of examinations for a range of core damage, but only cursorily reported on the expected core damage. A review of the detailed core damage assessments is needed to help narrow the scope of the planning.

Thus, the purpose of this report is to review and summarize the core damage assessments which have been made, identify the minimum and maximum bounds of damage, and establish a "reference" description for the current status of the core. The different degrees of damage present in the reference core will be considered during planning of contingency tooling and procedures for reactor disassembly, fuel removal, core inspection, and fuel sample acquisition.

Possible damage to the reactor core has been analyzed. The core damage assessments were generally of three types:

1. Reconstruction of the transient thermal-hydraulic behavior of the system by using interpretations of data available from in-core and outside-of-core instrumentation and computer code analyses;

2. Analyses of the amount of hydrogen produced; and

3. Evaluation of the amount of fission products released. 
Numerous uncertainties exist in each type of assessment due to the equivocal nature of the available data.

Section 2 of this report describes the thermal-hydraulic analyses of core damage. Analyses of the core damage using data on hydrogen generation and fission product release are discussed in Sections 3 and 4, respectively. Section 5 summarizes the best estimate damage to the core components and defines a "reference" core. Appendix A outlines some relevant design parameters of the TMI-2 reactor core. Appendix $B$ specifies the equations to determine the amount of zircaloy oxidized from the total hydrogen produced. The inventory and distribution of zircaloy in the core are presented in Appendix $C$. Appendix D describes the method of constructing illustrations of the core damage limits. 


\section{THERMAL-HYDRAULIC EVENTS}

Several investigators (see References 2 through 8 ) have attempted to reconstruct the sequence of thermal-hydraulic events in the TMI-2 core and primary system as one method of assessing core damage. They have used known events from $\log$ books and reactimeter data, information deduced from instrumentation that was often used for measuring parameters other than the ones originally intended (such as obtaining liquid level data from neutron detectors), and thermal-hydraulic principles and computer models to arrive at a consistent set of events.

The investigators agree that the core experienced no damage during the first 100 minutes into the accident. The reactor was shut down and produced energy at decay heat levels that was being removed by the prinary coolant pumps. Although the core remained fully covered by water, the pilot operated relief valve (PORV) on the pressurizer discharge piping remained open, causing a decrease in pressure and a loss of coolant inventory from the primary coolant system. At 73 minutes into tne accident, the primary coolant pumps in the $B$ loop were stopped and at 100 minutes, the A loop pumps were stopped. As a result of the loss in primary coolant flow and the continued loss of coolant through the PORV, the core began to uncover. The core did not become covered again until about 210 minutes.

Most, if not a 11, of the damage to the core is believed to have occurred between 100 minutes and 210 minutes. This section briefly summarizes the results of the thermal-hydraulic studies as they relate to the behavior of the core materials during this period and to the core status at present. 


\subsection{Transient Water-Steam Mixture Level}

During core uncovery, the two-phase steam and water mixture, which had been homogeneous during forced flow, separated. Steam collected in the high regions of the primary system. Below the water-steam mixture level, the coolant was near or at saturation, and heat transfer from the fuel rods to the coolant kept the rods near the saturated coolant temperatures. Relatively inefficient heat transfer occurred above the mixture level and fuel rod temperatures increased dramatically. Thus, the transient mixture level is significant in defining the extent of damage. Below an elevation that is a short distance above the mixture level, the zircaloy will remain relatively cool and retain its mechanical properties. At nigher elevations, the zircaloy will become hot enough to react with steam, becoming oxidized and embrittled. Figure 1 summarizes the time-dependent water-steam mixture level in the core as determined by several investigators. Information obtained by these investigators is discussed in the following sections by organization.

\subsubsection{Nuclear Safety Analysis Center}

According to the Nuclear Safety Analysis Center (NSAC), ${ }^{2,3}$ the initiation of core uncovery occurred at about 113 minutes. The calculated water-steam mixture level in the core during this period, shown in Figure 1, was derived from calculated heat and mass balances and a variety of data from such instruments as the outside-of-core source range detectors and in-core self-powered neutron detectors (SPNDS). Although the block valve on the PORV piping was closed at 140 minutes, the decrease in the core mixture level was still expected to continue. The mixture was expected to drop to the 1 metre $(3.3 \mathrm{ft}$ ) elevation at 174 minutes and then begin to increase. However, after 174 minutes the mixture level was not well characterized. 


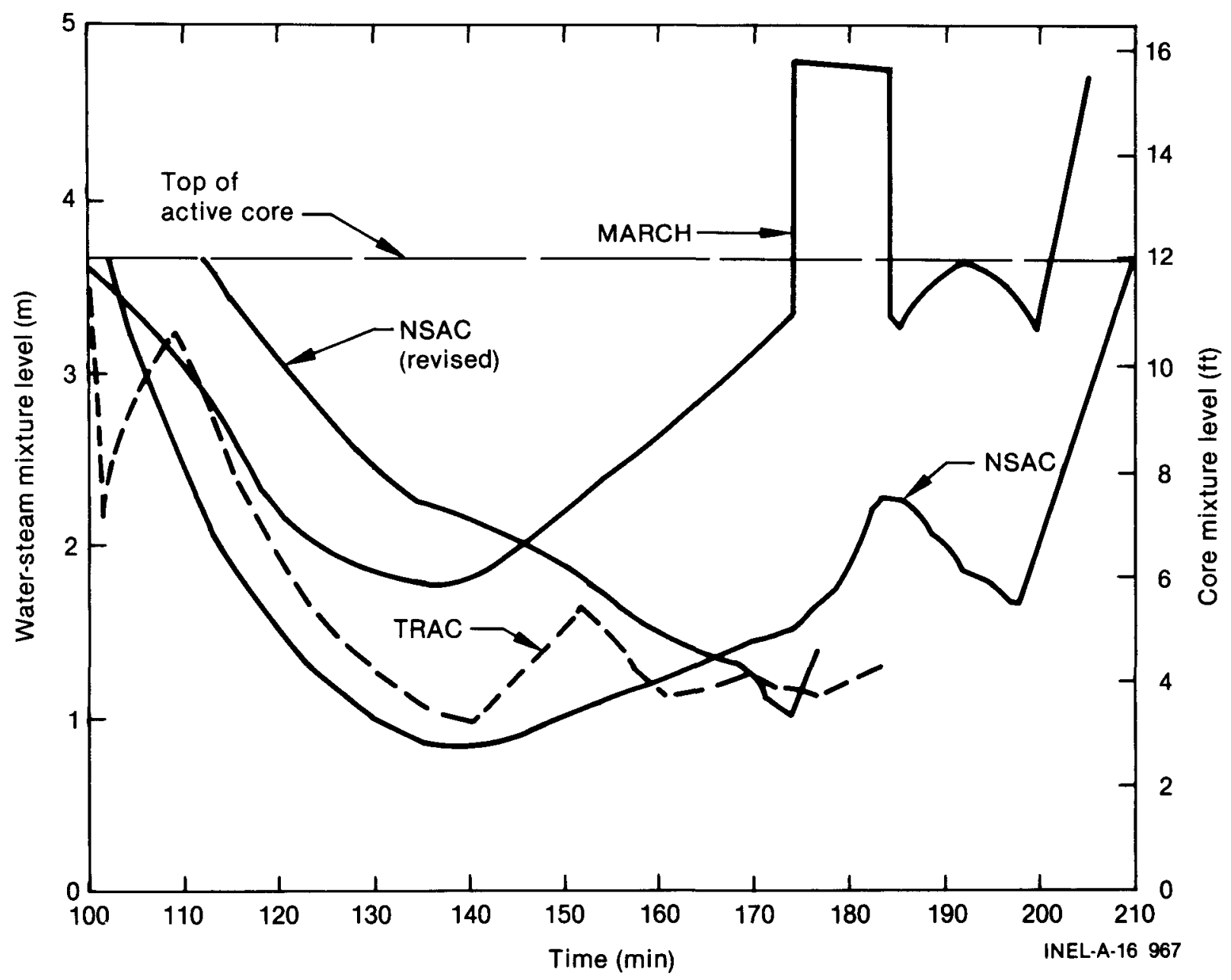

Figure 1. Water-steam and core-mixture levels during uncovery from 100 to 210 minutes. 


\subsubsection{Nuclear Regulatory Commission Special Inquiry Group}

A slightly different mixture level history was outlined by the Nuclear Regulatory Commission (NRC) Special Inquiry Group, ${ }^{4}$ although it is not specified in enough detail to be included in Figure 1 . Core uncovery is believed to have started between 102 minutes and 112 minutes. An engineering code, TMIBOIL, ${ }^{9}$ was used to calculate the fuel rod temperatures and core damage parametrically. The studies were performed varying the minimum core mixture level, boiloff rate, radial peaking factors, and conduction heat transfer coefficients. The damage calculated for each scenario was compared with the amount of hydrogen generated, fission product release, and maximum recorded temperatures. Based on these analyses, a scenario in which the core mixture level dropped to $1.2 \pm 0.15 \mathrm{~m}(4.0 \pm 0.5 \mathrm{ft})$ above the bottom of the core, and achieved a steady-state level after 120 minutes correlated well with the available data. At 130 minutes, the primary system pressure began to rise, and at about 140 minutes, the block valve to the open PORV was closed, stopping the loss of primary coolant. The primary system pressure continued to increase and the coolant mixture level in the core began to rise.

\subsubsection{Los Alamos Scientific Laboratory}

The Los Alamos Scientific Laboratory (LASL) performed Transient Reactor Analysis Code (TRAC) analyses of the thermal-hydraulic events. ${ }^{5,8}$ Estimated values for high pressure injection, letdown, and PORV flows were input to the code. Heat from fission product decay and the oxidation of zirconium were modeled. TRAC calculated core uncovery at 100 minutes. The coolant mixture level dropped to $1 \mathrm{~m}(3.3 \mathrm{ft})$ at 140 minutes, the time at which the block valve to the PORV was closed. The mixture level gradually stabilized at about $1.2 \mathrm{~m}(4.0 \mathrm{ft})$ where it remained until about 185 minutes, the time at which the calculation was terminated. 


\subsubsection{Battelle Columbus Laboratories}

The TMI-2 accident was also analyzed by Battelle Columbus Laboratories using MARCH, a code which predicts thermal and hydraulic conditions in the primary coolant system and containment building for hypothetical core melt accident senarios. 6 Boundary conditions input to MARCH were varied within their uncertainties to yield approximately $20 \%$ of the core at temperatures greater than $2550 \mathrm{~K}\left(4130^{\circ} \mathrm{F}\right)$. This represents an upper bound on the fuel temperatures based on examination of the data on radioactivity release to the containment, and maximizes the sensitivity of the core response to variations in alternative event sequences. Initiation of core uncovery was calculated to occur at 101 minutes. At about 135 minutes, a minimum collapsed liquid level of $1.7 \mathrm{~m}(5.5 \mathrm{ft})$ was calculated. The mixture level decreased at a rate approximately $50 \%$ faster than expected by boiloff due to decay heat because steam condensation in the steam generator was depressurizing the primary system and causing additional flashing. After 142 minutes, corresponding to block valve closure, the mixture level increased, rising to $2.4 \mathrm{~m}(8 \mathrm{ft})$ at 160 minutes.

\subsubsection{Westinghouse-Nuclear Energy Systems}

Westinghouse Nuclear Energy Systems (W-NES) performed calculations of the TMI-2 accident for the President's Commission to evaluate degraded core cooling for four different degrees of core damage. 7 One set of analyses treated an originally intact core representative of TMI-2. Core and system conditions at 100 minutes were obtained from NSAC. ${ }^{10}$ A best-estimate, net makeup flow of $2.6 \mathrm{~kg} / \mathrm{s}(41 \mathrm{gpm})$ was assumed. For the purposes of the analyses, closure of the block valve, operation of the nigh-pressure injection system after 100 minutes, and restart of the primary coolant pump after 100 minutes were assumed not to occur, although a 11 three of these assumptions were inconsistent with the actual TMI-2 transient. The calculated time-dependent core mixture level was in close agreement with the original NSAC estimate; ${ }^{10}$ the predicted minimum level was about $0.9 \mathrm{~m}$ $(3 \mathrm{ft})$. 


\subsubsection{Summary}

The variablility of the water-steam mixture level results summarized in Figure 1 may, in part, be explained by parametric analyses using MARCH which indicated that the calculated results were sensitive to the net makeup/letdown flow rate due to uncertainties in the high pressure injection and letdown line flow rates. The net inlet flow rates used in some of the analyses and the fuel rod behavior parameters which are affected by the flow rate are summarized in Table 1. As might be expected, as the net inlet flow decreases, the minimum mixture level generally decreases, fuel temperatures increase, and the arnount of zircaloy oxidized increases.

\subsection{Core Damage}

During the period of core uncovery from about 100 minutes to 174 minutes, the fuel rods were heating up. As cladding temperatures reached a range of about $1030 \mathrm{~K}\left(1395^{\circ} \mathrm{F}\right)$ to $1150 \mathrm{~K}\left(1610^{\circ} \mathrm{F}\right)$, rupture of the rods began to occur. ${ }^{2,4}$ Since virtually all the rods reached temperatures of this magnitude, greater than $90 \%$ of the rods are expected to have failed. ${ }^{2,4}$ The best estimate of the time of failure ranges from 137 to 142 minutes after the start of the accident. ${ }^{2}$ This coincides well with an estimated three-minute transport time of the fission products to the containment radiation monitors which responded at 145 minutes.

The cladding continued to heat up, becoming oxidized and embrittled. This exothermic reaction contributed to the rapid heatup of the core. Hot zircaloy in the upper regions of the core may have become fully oxidized. As the heat source from oxidation decreased, the oxidized cladding would have cooled. Steam rising from the lower regions of the core carried energy from the peak power locations to the upper region of the core, thus smearing the fuel rod temperatures and the axial extent of cladding oxidation. 11 Approximately the upper half of the core was embrittled. Detailed estimates of the amount of zircaloy oxidized are discussed in Section 3 . 
TABLE 1. VARIATION IN ESTIMATED NET INLET FLOW RATES BETWEEN 100 AND 200 MIN.

\begin{tabular}{|c|c|c|c|c|c|}
\hline & $\begin{array}{l}\text { Net Inlet } \\
\text { F low Rate } \\
(\mathrm{kg} / \mathrm{s}) \\
\end{array}$ & $\begin{array}{c}\text { Minimum } \\
\text { Mixture } \\
\text { Leve. } \\
(\mathrm{m}) \\
\end{array}$ & $\begin{array}{c}\text { Fuel } \\
\text { Rod Peak } \\
\text { Temperature } \\
(\mathrm{K}) \\
\end{array}$ & $\begin{array}{c}\text { Fraction of } \\
\text { Core } \\
>2550 \mathrm{~K} \\
\left(>4130^{\circ} \mathrm{F}\right) \\
\end{array}$ & $\begin{array}{c}\text { Fraction of } \\
\text { Cladding } \\
\text { Oxidized } \\
\end{array}$ \\
\hline $\begin{array}{l}B C L-M A R C H^{6} \\
(\text { nigh ECC })\end{array}$ & 6.9 & -- & 22550 & 0.01 & 0.02 \\
\hline $\begin{array}{l}\text { BCL-MARCH6 } \\
\text { (base case) }\end{array}$ & 5.7 & 1.8 & $>2550$ & 0.24 & 0.15 \\
\hline $\begin{array}{l}\text { BCL-MARCH6 } \\
(10 w E C C)\end{array}$ & 4.4 & -- & $>2550$ & 0.42 & 0.24 \\
\hline W-NES 7 & 2.6 & $20.9^{C}$ & 2880 & - & $>0.33^{d}$ \\
\hline NRC & $1.6^{\mathrm{e}}$ & -- & -- & -- & -- \\
\hline$N S A C^{2}$ & $f$ & 0.97 & - & -- & - \\
\hline $\begin{array}{l}\text { LASL- } \\
\text { TRAC } 5,12\end{array}$ & $\begin{array}{l}-12.89 \\
-4.59 \\
09\end{array}$ & $\sim 1$ & $\begin{array}{l}\sim 1800, n \\
2500^{h}\end{array}$ & -- & $<0.13^{i}$ \\
\hline
\end{tabular}

a. $1 \mathrm{~kg} / \mathrm{s}=15.87 \mathrm{gpm}$, assuming that the density of water is $1 \mathrm{~g} / \mathrm{mL}$ (8.35 lb/gal).

D. $1 \mathrm{~m}=3.28 \mathrm{ft}$.

c. Based on close agreement with Reference 10.

d. Top $1.2 \mathrm{~m}(4 \mathrm{ft})$ of core was $100 \%$ oxidized.

e. Letter, L. S. Tong to M. Cunningnam, Attachment III, "Best Estimate Initial and Boundary Conditions for TMI-2 Analyses," USNRC, July 26, 1979 (see Reference 6).

f. May be negative (see Reference $6 \mathrm{pp}$. 4-2).

g. Assumed net inlet flow rate for $101 \mathrm{~min}<\mathrm{t}<120 \mathrm{~min}=-12.8 \mathrm{~kg} / \mathrm{s}$

$(-203 \mathrm{gpm}) ; 120 \mathrm{~min}<\mathrm{t}<138 \mathrm{~min}=-4.5 \mathrm{~kg} / \mathrm{s}(-71.4 \mathrm{gpm})$;

$\mathrm{t}>138 \mathrm{~min}=0$.

n. About $1800 \mathrm{~K}\left(2780^{\circ} \mathrm{F}\right)$ was calculated by TRAC at $180 \mathrm{~min}$; extrapolation of the TRAC results to $200 \mathrm{~min}$ yields about $2500 \mathrm{~K}\left(4040^{\circ} \mathrm{F}\right)$ in the nottest core regions.

i. Calculated maximum oxidation at nottest axial location extrapolated to the total core yields $130 \mathrm{~kg}(287 \mathrm{lbm})$ of hydrogen at $185 \mathrm{~min}$, which is equivalent to oxidizing about $13 \%$ of the cladding (Reference 26). 
A range of peak fuel rod temperatures has been estimated. Based on TRAC calculations, peak temperatures were estimated to be $2400 \mathrm{~K}^{8}$ $\left(3860^{\circ} \mathrm{F}\right)$ to $2600 \mathrm{~K}^{12}\left(4220^{\circ} \mathrm{F}\right)$ before resumption of high pressure injection flow. Fuel rod plenum temperatures were estimated to be about $1700 \mathrm{~K}^{12}\left(2600^{\circ} \mathrm{F}\right)$. NRC's Special Inquiry Group and W-NES estimated slight ly higher peak fuel temperatures of $2700 \mathrm{~K}^{4}\left(4400^{\circ} \mathrm{F}\right)$ and $2900 \mathrm{~K}^{7}$ $\left(4760^{\circ} \mathrm{F}\right)$, respectively. The President's Commission concluded that the fuel temperatures may have exceeded $2475 \mathrm{~K}\left(4000^{\circ} \mathrm{F}\right)$ throughout 30 to $40 \%$ of the core volume, and $2200 \mathrm{~K}\left(3500^{\circ} \mathrm{F}\right)$ throughout the upper 40 to $50 \%$ of the core. ${ }^{13}$ These estimates are nigher than the estimate by $\mathrm{NSAC}^{14}$ that the gross core average temperatures did not exceed $2000 \mathrm{~K}\left(3140^{\circ} \mathrm{F}\right)$. However, a quantitative comparison cannot specifically be made since NSAC specified neither the size of the damaged region nor the peak temperatures.

At temperatures above $2175 \mathrm{~K}\left(3455^{\circ} \mathrm{F}\right)$, it has been experimentally observed ${ }^{15}$ that the $\mathrm{UO}_{2}$ fuel pellets, in contact with the cladding, can be dissolved by the zircaloy, forming a liquid phase of $\mathrm{Zr}-\mathrm{U}-0$ termed "liquified fuel." Essentially all investigators expected that liquified fuel would have been produced in small quantities, but that little or no fuel melting occurred. ${ }^{13,14}$ NRC's evaluation is somewhat more pessimistic, suggesting that no less than $32 \%$ of the fuel assemblies have fingers of previously liquified fuel extending below the region of primary damage. 4

Estimates of the damage to other core components, whose materials and melting points are tabulated in Appendix A, can be made from these temperatures. Calculations performed using radiative and convective heat transfer between fuel rods, steam, and nonfueled rods such as control rod guide tubes and burnable poison rods indicate that the temperature of the non-fueled rods may only have been about $10 \mathrm{~K}\left(18^{\circ} \mathrm{F}\right)$ less than that of the fuel rods. ${ }^{16}$ However, for the period up to 174 minutes in the accident, the NRC Special Inquiry Group ${ }^{17}$ suggested that "percolation" may have occurred in the instrument and control rod guide tubes: 
"Instrumentation tubes and control rod guide tubes survived longer than the neighboring fuel rods because they were not significant heat sources and because they served as 'percolator tubes' during depressurization, in which steam bubbles, formed in the annuli, caused liquid water to percolate above the average level in the core to reach higher temperature regions before evaporating. The net effect was to produce a much higher mass flow of steam, as well as velocity of steam flow, through the annuli between the guide tubes and the control rods (and in the double annuli of the instrumentation tubes) than occurred in the subchannels between neighboring fuel rods. Thus, the guide tubes, control rods, and instrumentation tubes stayed much cooler than otherwise expected during depressurization and, consequently, lagged significantly in temperature rise compared with their surroundings. Their heatup started later, and the heat absorbed by them was transferred by radiation from neighboring fuel rods and by conduction-convection interaction with the steam in the fuel subchannels."

Recent evidence suggests that the instrument tubes may not have survived. Figure 2 is a cross section of the instrument string comprised of seven SPNDS, one thermocouple, and one background detector. The Inconel oversheath is the primary pressure boundary and the Inconel center tube is the secondary pressure boundary. A swagelock fitting on the instrument string acts as a third pressure boundary. After removing the swagelock fitting on one instrument string, a traveling in-core probe (TIP) was inserted into the central hole of the instrument string that was located in the center of the $\mathrm{N}-8$ assembly at about the mid-radius of the core, four rows from the center assembly as shown in Figure 3 (based on Reference 3 ). The TIP was partially inserted, perhaps as high as $1 \mathrm{~m}(3.3 \mathrm{ft})$ above the bottom of the core, with great difficulty before being withdrawn. 18,19 During removal, the detector stuck several feet below the core and is currently immovable. Magnesium oxide insulation in the TIP is known to swell when in contact with water. Tne inner tube of the instrument string is the last pressure boundary for the assembly with the TIP inserted. White boric acid crystals are present on the concrete floor where the in-core detectors originate. Although the boric acid crystals cannot be confirmed as being deposited from water emanating from the instrument string with the TIP, this observation is consistent with the postulation 


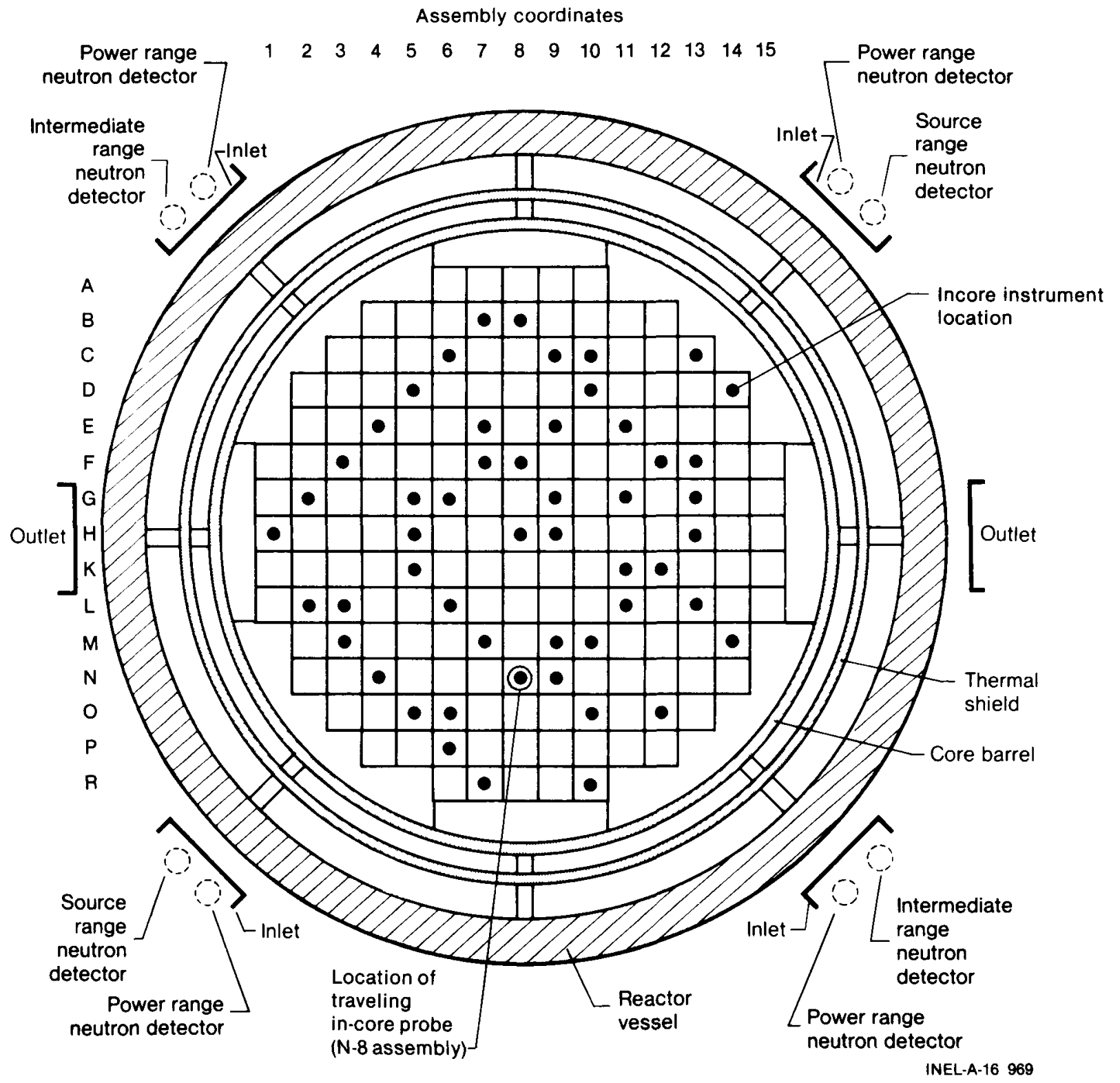

Figure 2. In-core instrumentation position. 


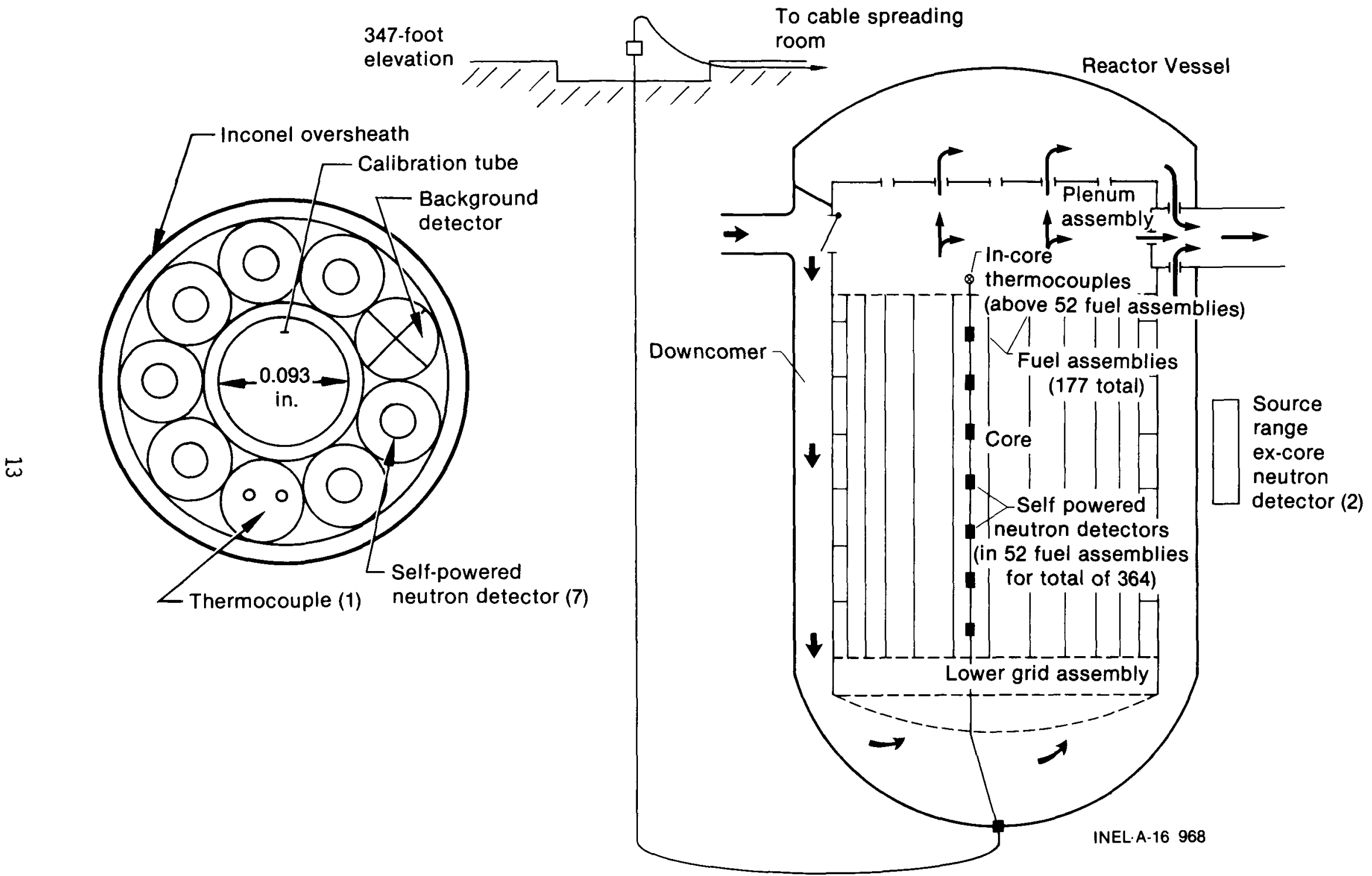

Figure 3. A top view of the reactor core, illustrating location of the traveling in-core probe. 
that that particular instrument string has failed. If this is in fact the case for an assembly at the midradius of the core, then it is very possible that a large majority of the instrument strings in the central region of the core have failed.

The axial power shaping rods, control rods, and burnable poison rods were also damaged. Since the melting points of the silver-indium-cadmium alloy and the 304 stainless steel are about $1075 \mathrm{~K}\left(1475^{\circ} \mathrm{F}\right)$ and $1675 \mathrm{~K}$ $\left(2555^{\circ} \mathrm{F}\right)$, respectively, these rods melted over much of the same volume of the core in which the fuel rods were oxidized. The Ag-In-Cd alloy probably remained in the core region since it is insoluble in water. Both materials contributed to formation of the debris bed and fusing of portions of the rubble. The zircaloy cladding of the burnable poison rods oxidized over the same region as the cladding on the fuel rods so these rods are in the same fragmented condition. The rods are probably in place, but the boron absorber is known to leach out in the presence of water in a radiation environment. Gadolinia burnable poison rods $\left(\mathrm{UO}_{2}-\mathrm{Gd}_{2} \mathrm{O}_{3}\right)$ in two test assemblies are also oxidized and fragmented. Since the melting point of Inconel 718 is about $1550 \mathrm{~K}\left(2330^{\circ} \mathrm{F}\right)$, the grids would have melted over most or all of the region of the core in which the fuel rods were oxidized. The zircaloy guide tubes may have oxidized over a region somewhat smaller than that of the fuel rod cladding due to the early percolation effect, however, they are expected to have contributed to the material in the debris bed.

Temperatures of the upper plenum assembly were calculated by TRAC $^{5}$ to have reached $1100 \mathrm{~K}\left(1520^{\circ} \mathrm{F}\right)$ at 185 minutes into the transient, a time when peak fuel temperatures were calculated by TRAC to be $1800 \mathrm{~K}$ $\left(2780^{\circ} \mathrm{F}\right) .^{5,12}$ Calculated fuel rod plenum temperatures were $1200 \mathrm{~K}$ $\left(1700^{\circ} \mathrm{F}\right) .^{12}$ The fuel rod plenum and peak fuel temperatures were extrapolated to about $1900 \mathrm{~K}\left(2960^{\circ} \mathrm{F}\right)$ and $2600 \mathrm{~K}\left(4220^{\circ} \mathrm{F}\right),^{12}$ respectively, before resumption of high pressure injection flow at about 200 minutes. Although these investigators did not extrapolate their analyses of the upper plenum assemoly, in view of their estimates for the other temperatures, it is possible that the temperatures of the upper plenum could have risen to between $1500 \mathrm{~K}\left(2240^{\circ} \mathrm{F}\right)$ and $1800 \mathrm{~K}\left(2780^{\circ} \mathrm{F}\right)$. 
Temperatures in this range would imply, first, that brazemerits of Beryllium-Nickel 5 that hold the control rod guides to structural support plates in the upper plenum would have melted since they have a melting range of 1365 to $1420 \mathrm{~K}\left(2000\right.$ to $\left.2100^{\circ} \mathrm{F}\right)$. Second, stainless stee 1 components, such as the fuel assembly upper end fittings which have a melting range of 1670 to $1695 \mathrm{~K}\left(2550\right.$ to $\left.2590^{\circ} \mathrm{F}\right)$, would have melted or fused at their contact points with the plenum. Spider failure and leadscrew distortion would be likely.

At 174 minutes, with the coolant mixture level at about $1.5 \mathrm{~m}(4.9 \mathrm{ft})$ above the bottom of the core, one primary coolant pump in the B loop was turned on for 19 minutes. This produced a sudden influx of water to the core from the once-through steam generator (OTSG) B. Since the cladding was embrittled due to oxidation, the entering water would have produced a thermal shock to the cladding, causing fragmentation of the $\mathrm{ZrO}_{2}$ and $\mathrm{UO}_{2} \cdot{ }^{20}$ This would have either formed a debris bed above the axial midplane of the core or increased the size of one already present. Although substantial quenching of the rods occurred, the debris bed itself remained hot and in steam.

The next major change in core condition occurred between 222 minutes and 226 minutes into the accident. The source range monitors showed a sharp increase in activity, the primary system pressure increased even though the block valve was open, and the cold leg temperatures of both the $A$ and $B$ loops increased. Temperature estimates from thermocouple and SPND data indicate that temperatures of $800 \mathrm{~K}\left(980^{\circ} \mathrm{F}\right)$ were reached at locations 25 to $75 \mathrm{~cm}$ ( 10 to $30 \mathrm{in.}$ ) above the bottom of the fuel rods.

Although it is educated speculation, additional core damage apparently occurred during this time. Given the oxidized and embrittled cladding before about 225 minutes, it is possible that "unstable thermal-hydraulic conditions" ${ }^{3}$ developed to fracture additional cladding, resulting in some additional slumping of the core and densification of the debris bed. 3,4 A steam blanket may have formed below a crust in the bed, blocking coolant 
and permitting additional zircaloy oxidation and hydrogen formation. Based on available instrumentation, no apparent change in the condition of the core occurred after the event at about 226 minutes.

Independent assessments of the core flow resistance following the accident were made by Babcock and Wilcox (B\&W) and Battelle Pacific Northwest Laboratories (PNL). 19 The assessments indicated that a large portion of the core was blocked. B\&W made two estimates by comparing reactor coolant system flow meter readings, with one pump operation, before and after the accident and performing a core heat balance after the accident. The estimated decay heat and measured core coolant temperature change determined the flow. An effective blockage area of about $90 \%$ was indicated. PNL performed COBRA calculations to reproduce the TMI-2 core exit temperature distribution during single loop operation, as well as a simple heat balance using the average of measurements from the core exit thermocouples located at the top of the instrument tubes. They estimated blockages of 60 to $80 \%$, with local blockages of $95 \%$. An effective core blockage area of $90 \%$ was also estimated by performing a simple core heat balance using the average core exit thermocouple readings on the periphery of the core. From these three assessments, it was concluded that an effective core flow area blockage of approximately $90 \%$ had occurred. Temperatures in the peripheral assemblies indicated that the minimum blockage occurred in the peripheral assemblies. However, since more than $20 \%$ of the core flow area is made up by the peripheral assemblies, some blockage at the edge of the core is expected.

Damage parameters from the three primary assessments are summarized in Table 2. With the exception of the estimated fuel temperature, the expected damage is quite consistent.

Based on the foregoing review, the core condition can be described in the following manner. A debris bed of fractured, oxidized zircaloy cladding and fragmented fuel pellets rests on fuel rod stubs and Inconel spacer grids. The debris bed extends downward to between 0.9 and $1.8 \mathrm{~m}$ 
TABLE 2. SUMMARY OF CORE DAMAGE ESTIMATES BASED ON RECONSTRUCTION OF THE ACCIDENT

\begin{tabular}{|c|c|c|c|c|}
\hline $\begin{array}{c}\text { Damage } \\
\text { Parameter }\end{array}$ & NSAC $^{14}$ & $\begin{array}{l}\text { President's } \\
\text { Commission } \\
\end{array}$ & $\begin{array}{l}\text { NRC Special } \\
\text { Inquiry Group }\end{array}$ & LASL $^{12}$ \\
\hline $\begin{array}{l}\text { Number of } \\
\text { failed rods } \\
(\%)\end{array}$ & -- & $>90$ & 100 & 100 \\
\hline \multirow[t]{2}{*}{$\begin{array}{l}\text { Fuel } \\
\text { temperature }\end{array}$} & $\begin{array}{l}\text { Gross average in } \\
\text { damaged region } \\
<2000 \mathrm{~K} \\
\left(<3140^{\circ} \mathrm{F}\right)\end{array}$ & $\begin{array}{l}\text { Distribution: } \\
\text { a. }>2200 \mathrm{~K} \\
\left(>3500^{\circ} \mathrm{F}\right) \\
\text { in } 40 \text { to } 50 \% \text { of } \\
\text { core }\end{array}$ & $\begin{array}{c}\text { Peak } \\
2700 \mathrm{~K} \\
\left(2400^{\circ} \mathrm{F}\right)\end{array}$ & $\begin{array}{c}\text { Peak } \\
22600 \mathrm{~K} \\
\left(24220^{\circ} \mathrm{F}\right)\end{array}$ \\
\hline & & $\begin{array}{l}\text { b. }>2475 \mathrm{~K} \\
\left(>3995^{\circ} \mathrm{F}\right) \\
\text { in } 30 \text { to } 40 \% \text { of } \\
\text { core }\end{array}$ & & \\
\hline $\begin{array}{l}\text { Liquified } \\
\text { fuel }\end{array}$ & Locally possible & Yes & $\begin{array}{l}\text { Yes, over most of } \\
\text { core radius }\end{array}$ & $\begin{array}{l}\text { Yes, over most } \\
\text { of core radius }\end{array}$ \\
\hline $\begin{array}{l}\text { Molten } \\
\text { fuel }\end{array}$ & $\begin{array}{l}\text { Locally possible, } \\
\text { very limited }\end{array}$ & -- & -- & -- \\
\hline $\begin{array}{l}\text { Core slumping } \\
\text { at } 225 \mathrm{~min}\end{array}$ & Probable & Probable & Yes & -- \\
\hline $\begin{array}{l}\text { Fuel rod } \\
\text { fragmentation }\end{array}$ & Yes & Yes & Yes & Yes \\
\hline Damage level & $\begin{array}{l}\text { Embrittlement } \\
\text { extends down to } \\
0.9 \text { to } 1.8 \mathrm{~m} \\
(3.0 \text { to } 5.9 \mathrm{ft}) \text { from } \\
\text { bottom of core } \\
\text { at centerline. } \\
\text { Peripheral rods } \\
\text { relatively intact. }\end{array}$ & $\begin{array}{l}\text { Debris extends down } \\
\text { to } 1.4 \text { to } 1.5 \mathrm{~m} \\
(4.6 \text { to } 4.9 \mathrm{ft}) \\
\text { from bottom of } \\
\text { core at centerline. }\end{array}$ & $\begin{array}{l}\text { Embrittlement } \\
\text { extends down to } \\
1.2 \text { to } 1.5 \mathrm{~m} \\
(3.9 \text { to } 4.9 \mathrm{ft}) \\
\text { from bot tom of } \\
\text { core at centerline. }\end{array}$ & $\begin{array}{l}\text { Embrittlement } \\
\text { extends down } \\
\text { to } 1.0 \mathrm{~m} \\
(3.3 \mathrm{ft}) \\
\text { from bottom of } \\
\text { core at } \\
\text { centerline. }\end{array}$ \\
\hline
\end{tabular}


( 3 and $6 \mathrm{ft}$ ) above the bottom of the core at its center. The debris boundary extends outward and upward from its lowest point near the core centerline, encompassing a volume in the shape of an inverted bell. Damage to the rods near the periphery ranges from moderately intact (not fully embrittled) to partially liquified and oxidized. Liquified fuel formed, fusing core components and deoris in several areas. Some of the upper plenum components could have partially melted or fused together at their contact points. 


\section{HYOROGEN GENERATION}

A number of mechanisms in light water reactors may result in the generation of hydrogen. One mechanism is radiolysis, in which water decomposes into hydrogen and oxygen as a result of the absorption of energy from ionizing radiation. Oxidation of $\mathrm{UO}_{2}$ fuel and structures within the core is also a potential source. However, for the TMI-2 accident, the generation of hydrogen by these processes is expected to have been small when compared with the volume of hydrogen that was produced by oxidation of the zirconium in the fuel rod cladding by the steam in the reactor vessel. 4 Assessment of the amount of hydrogen generated yields an additional estimate of the amount of zircaloy oxidized, and hence embrittled, in the reactor core. This section dicusses the hydrogen inventory analyses, zircaloy oxidation, and computer code calculations of this aspect of the TMI-2 accident.

\subsection{Hydrogen Inventory}

Material balances were used by several investigators to determine the amount of zircaloy oxidized based on the amount of hydrogen produced. These balances are summarized in Table 3. EPRI 21 indicated that the material balances were performed using the reactor building as the boundary. Any hydrogen escaping the building would not be included. Since a maximum of $8 \%^{22}$ to $10 \%^{21}$ of the inventory of noble gases escaped from the reactor building during the first few days of the accident, at least 8 to $10 \%$ of the hydrogen might also be expected to have escaped. This would make estimates of the amount of zircaloy oxidized too low by the same amount. $^{21}$ However, if oxygen were depleted by oxidation of materials other than zircaloy, less oxidation of the zircaloy would result.

Table $4^{21,23,24}$ identifies the components of the containment atmosphere which was sampled twice on March 31, 1979 at about 0600 hours. The amount of hydrogen in the second sample is in question. As noted in the table, two different compositions were used by the various 
TABLE 3. HYDROGEN AND CLADDING INVENTORIES AND CLADDING OXIDATION

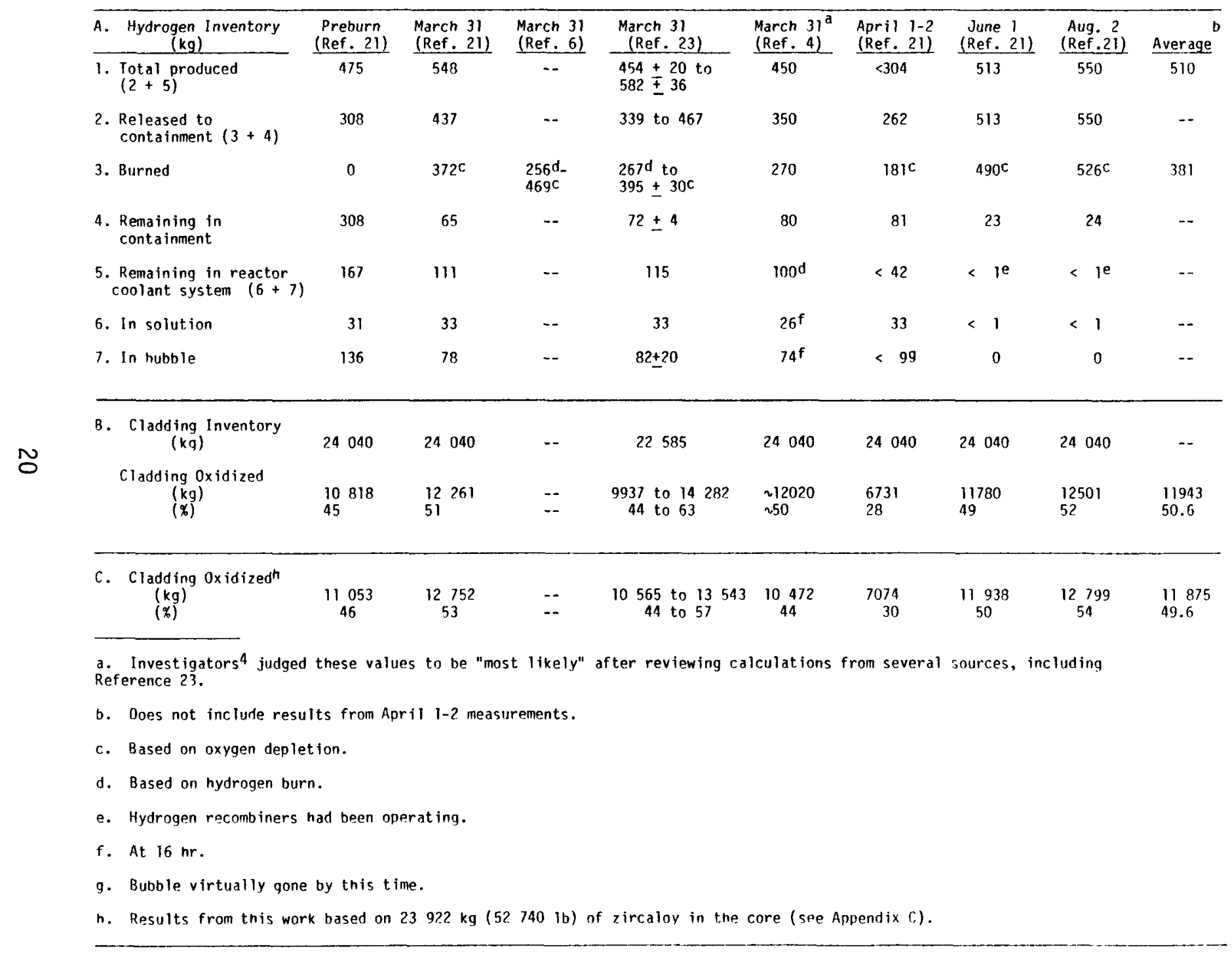


TABLE 4. CONTAINMENT ATMOSPHERE SAMPLES, MARCH 31, 1979 AT 0600 HOURS

\begin{tabular}{|c|c|c|c|}
\hline \multirow[b]{2}{*}{ Component } & \multicolumn{3}{|c|}{ Atmosphere Composition (at. \%) } \\
\hline & Sample 1 & Samp le $2 a$ & Sample 2b \\
\hline $\begin{array}{l}\mathrm{H}_{2} \\
\mathrm{O}_{2} \\
\mathrm{~N}_{2}\end{array}$ & $\begin{array}{l}1.7 \mathrm{a}, \mathrm{b} \\
15.7^{\mathrm{b}, \mathrm{c}} \\
82.6\end{array}$ & $\begin{array}{l}1.7^{b} \\
16.5^{b, c} \\
81.8\end{array}$ & $\begin{array}{l}1.9^{\mathrm{a}} \\
16.5^{\mathrm{b}, c} \\
81.6\end{array}$ \\
\hline \multicolumn{4}{|c|}{$\begin{array}{l}\text { a. Reference } 24 . \\
\text { b. Letter, Lavallee to Zebroski, NSAC, June 5, } 1979 \text { (in Reference 21). } \\
\text { C. Personal communication from A. D. Miller, NSAC, undated, to } \\
\text { R. E. English, President's Commission (in Reference 23). } \\
\text { Note: In analyses of the containment atmosphere, the following were used-- } \\
\text { References } 3,5 \text {, and } 21 \text { : Average of Samples } 1 \text { and } 2 a \text {; Reference 23: } \\
\text { Average of Samples } 1 \text { and } 2 b \text {. }\end{array}$} \\
\hline
\end{tabular}


investigators. Since the variability in hydrogen content of subsequent samples taken in April ${ }^{21}$ was of the magnitude of these two samples, $0.2 \%$, tnese results were judged to be the same. ${ }^{25}$ These and other containment atmosphere samples were used to calculate the amount of hydrogen remaining in the containment building and the amount burned by considering the oxygen depletion.

The preburn hydrogen inventory shown in Table 3 was calculated using the $0.19 \mathrm{MPag}$ (28 psig) pressure pulse in the containment building shown in Figure $4^{21}$ and the containment atmosphere composition. The amount of free hydrogen in the primary system was calculated based on estimates of bubole size by Metropolitan Edison, 24 and the temperature, pressure, and free volume of the containment building. Hydrogen in solution in the primary system was estimated based on the primary coolant temperature and the hydrogen overpressure.

Table 3, Section A, shows that, except for the calculated inventory based on the April 1 and 2 samples, estimates of the total amount of hydrogen produced are fairly consistent, averaging $510 \mathrm{~kg}(1125 \mathrm{lom})$ and ranging between 450 and $582 \mathrm{~kg}(992$ and $1283 \mathrm{lbm})$. The individual values comprising the total amount of hydrogen on April 1 and 2 that are low relative to the March 31 data are the hydrogen content in the bubole and amount of hydrogen burned. These low values result in a comparatively lower estimate of the percent of cladding oxidized. Note that a large uncertainty arises due to the methods of calculating the amount of hydrogen burned, namely, by using the remaining hydrogen concentration, or the oxygen depleted.

Section $B$ in Table 3 summarizes the cladding inventory and the amount of cladding oxidized as reported by the investigators. To place these results on a consistent basis in this work, the kilograms of zircaloy oxidized were calculated directly from the total amount of hydrogen produced using the equation in Appendix $B$. The percent of zircaloy oxidation was obtained by dividing the amount oxidized by the inventory, $23922 \mathrm{~kg}$ (52 $470 \mathrm{lbm}$ ), from Append ix C. 


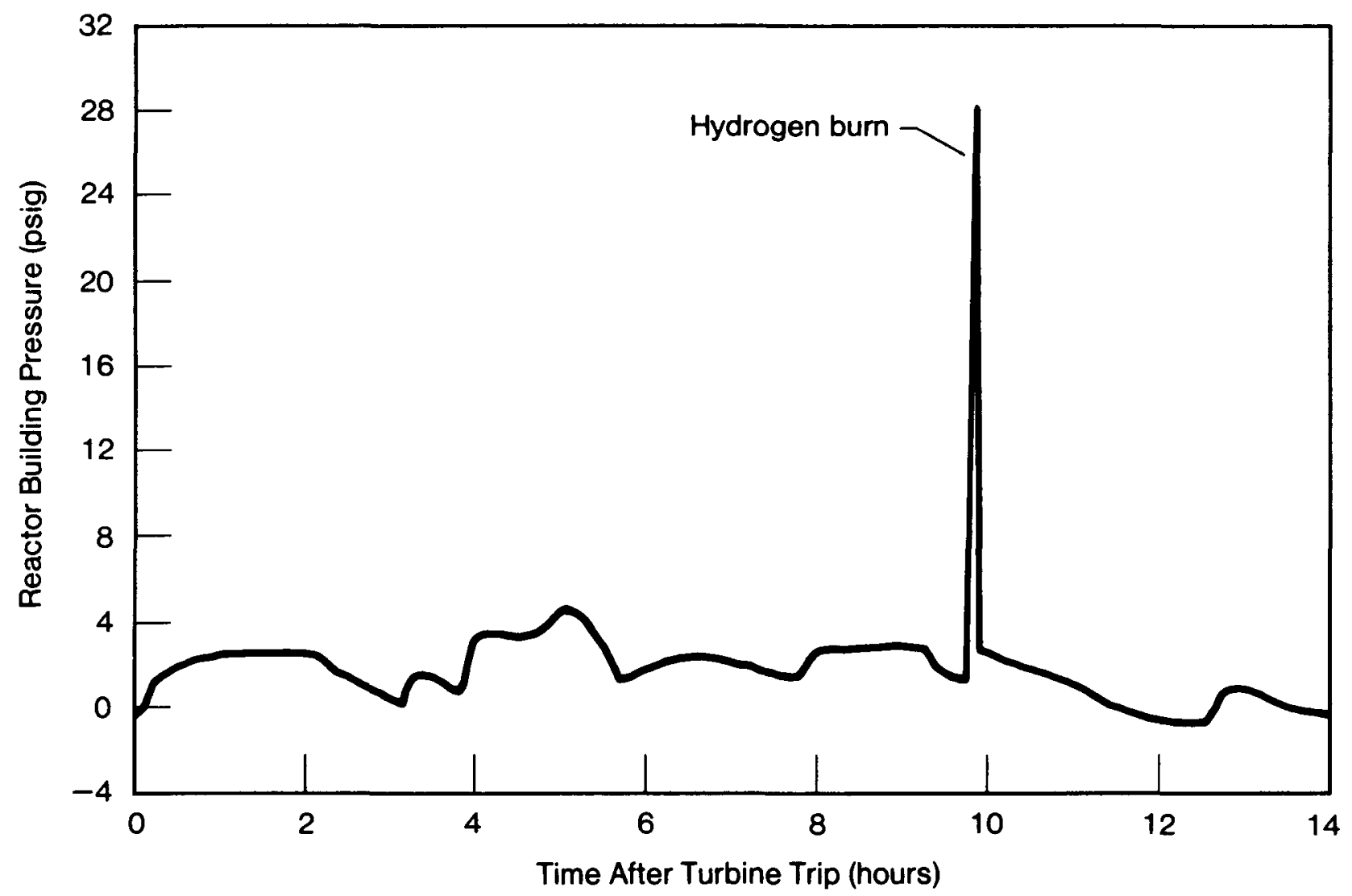

Figure 4. Pressure versus time in the reactor building after turbine trip. 
Since Sections $B$ and $C$ of Table 3 are not significantly different, it is concluded that about 50\% of the zircaloy, $11961 \mathrm{~kg}(262351 \mathrm{dm})$, in the core is oxidized. About 10\% of the zircaloy inventory, $2288 \mathrm{~kg}$ (4767 lbm), is in the plenum region of the fuel rods, as calculated in Appendix $C$. If it is assumed that none of the zircaloy in the plenum was oxidized, the fraction of the zircaloy in the active region of the core that was oxidized is determined by dividing $11961 \mathrm{~kg}(262351 \mathrm{bm})$ by $21634 \mathrm{~kg}$

$(47703 \mathrm{lbm})$. Thus, a maximum of $55 \%$ of the zircaloy in the active core region was oxidized. Since the rod plenum was estimated to have sustained temperatures up to $1900 \mathrm{~K}\left(2600^{\circ} \mathrm{F}\right)^{12}$ some oxidation is expected; thus, the actual amount of zircaloy oxidation in the active region of the core probably lies between $50 \%$ and $55 \%$. The accuracy of this value is estimated to be $n 10 \%$ of the inventory.

\subsection{Computer Code Calculations}

The amount of hydrogen generated was also calculated as part of several thermal-hydraulic analyses performed using TRAC ${ }^{5}$ and MARCH. ${ }^{6}$ Although the estimates of the hydrogen generated were generally well below the range of values in Table 3 , they are presented for completeness.

TRAC determined that melting of unoxidized cladding would begin to occur at 185 minutes into the transient, so the calculation was stopped. At that time, the outer third of the cladding thickness at the hottest axial node, located at a fractional core height of 0.75 , had been oxidized. If this amount of oxidation was extended on a corewide basis, $130 \mathrm{~kg}$ of hydrogen would have been generated. 26 Without extending this value on a corewide basis, TRAC predicted generation of approximately $40 \mathrm{~kg}$ of hydrogen. 27 Hydrogen generation continued during the accident at least until the core was recovered by coolant at around 210 minutes.

Since the MARCH code is designed to calculate thermal-hydraulic conditions in the primary system and containment building during a core meltdown accident, it was able to continue running for the full course of 
the accident. One assumption of the calculation was that $20 \%$ of the core was at a temperature greater than $2550 \mathrm{~K}\left(4130^{\circ} \mathrm{F}\right)$. At 185 minutes, the total hydrogen generated was calculated to be about $90 \mathrm{~kg}$ compared to $40 \mathrm{~kg}$ with TRAC. During the core uncovery period from 101 to 210 minutes, a total hydrogen production of $160 \mathrm{~kg}$ was calculated, corresponding to oxidation of $15.4 \%$ of the cladding.

The hydrogen production calculated by TRAC and MARCH is not considered to be accurate in view of the consistency of the hydrogen production deduced from the experimental measurements discussed in Section 3.1. One possible reason is that there is little or no data on zircaloy oxidation rates above 1700 to $1800 \mathrm{~K}\left(2600\right.$ to $\left.2780^{\circ} \mathrm{F}\right)$. This would impact the hydrogen generation rate. 


\section{FISSION PRODUCT RELEASE}

Assessments of the damage to the TMI-2 core based on analyses of fission product release are not as precise as those determined from thermal hydraulic calculations or from analyses based on hydrogen assays. However, the fission product release analyses are significant since they generally confirm the findings of the two other damage assessment methods.

The foundation of the fission product release damage assessments rests on: (a) calculated inventories of the various fission products and actinides; (b) samples of the primary coolant; (c) a sample of the containment building atmosphere; and, (d) a sample of water from the containment building sump. Analyses of the fission product inventory were performed by LASL ${ }^{28}$ using CINDER and EPRI-CINDER, and by Biw ${ }^{22}$ using their version of ORIGEN. Samples of primary coolant were taken from the letdown 1ine on March 29 and April 10, 1979 and sent to Bettis Atomic Power Laboratories (BAPL), Savannah River Laboratory (SRL), Oak Ridge National Laboratory (ORNL), and $B \& W$ for analysis; the results are presented in Table 5. ${ }^{23}$ In addition, a gas sample was obtained from the containment building atmosphere on March 31, 1979; the results from BAPL's analysis are in Table 6.29 A more complete accounting of the radioactivity inventory was achieved when a water sample from the containment building sump was obtained on August 28, 1979.

This section discusses the estimates derived from the above information regarding the location of core damage, the range of fuel temperatures achieved during the accident, the occurrence of $\mathrm{NO}_{2}$ fuel melting, and fuel particle size distributions.

\subsection{Location of Core Damage}

The location of core damage may be estimated by comparing the isotopic ratios of uranium and plutonium observed in the reactor sump to those expected for various regions of the core. Three ${ }^{235} U$ fuel enrichments 
TABLE 5. FISSION PRODUCTS IN THE REACTOR COOLANT FROM SAMPLES TAKEN ON MARCH 29 AND APRIL 10, 1979

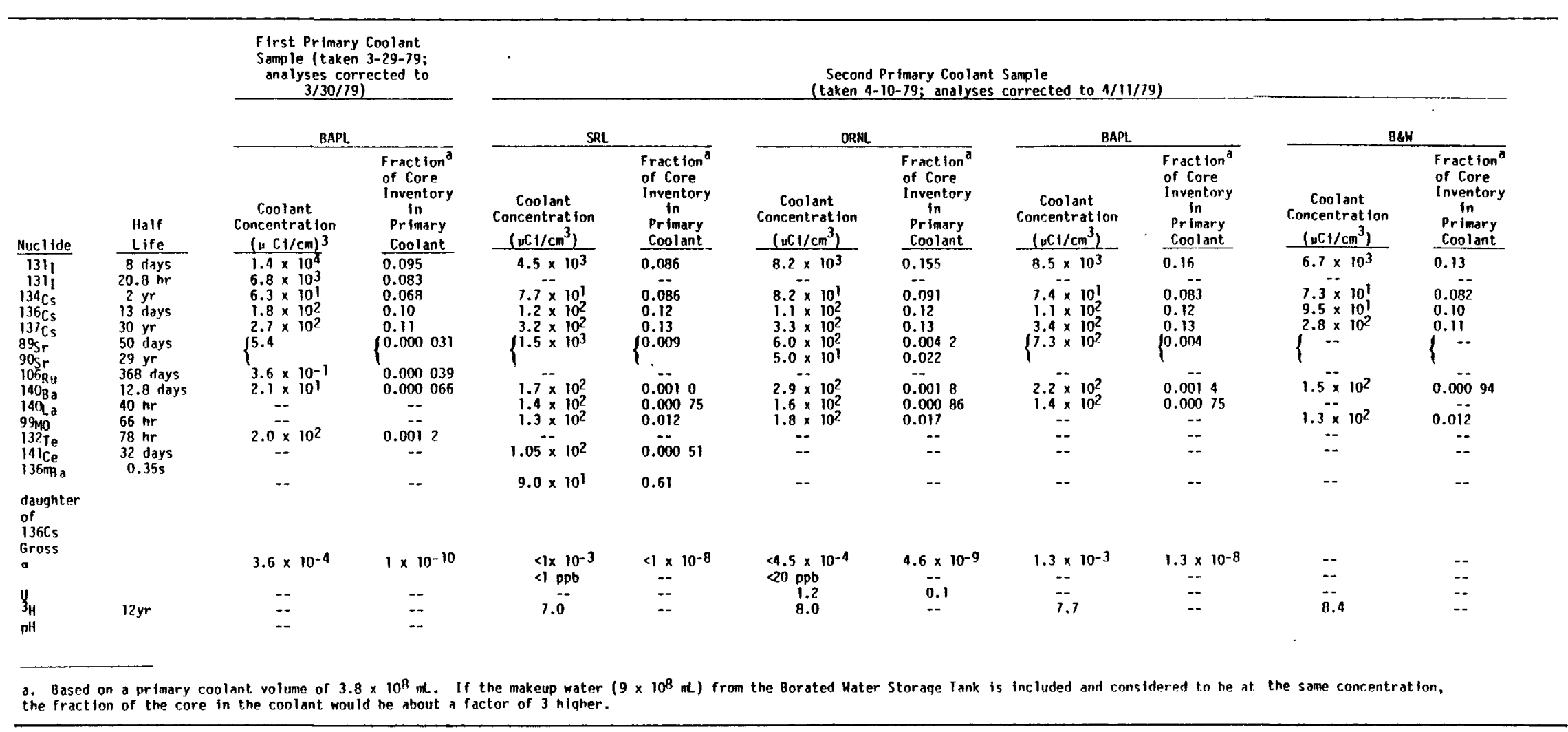


TABLE 6. RADIOACTIVITY OF GAS SAMPLE FROM CONTAINMENT BUILDING AIR, MARCH 31, 1979

\begin{tabular}{cc}
\hline Isotope & $\begin{array}{c}\text { Concentration } \\
(\mu \mathrm{C} / / \mathrm{mL})\end{array}$ \\
\hline $133 \mathrm{xe}$ & 676.0 \\
$133 \mathrm{mxe}$ & 16.0 \\
$135 \mathrm{Xe}$ & 8.1 \\
$131 \mathrm{I}$ & 0.063 \\
$133 \mathrm{I}$ & $<0.03$ \\
\hline
\end{tabular}


are present in the TMI-2 core, $1.98 \%, 2.64 \%$, and $2.96 \%$. The calculated isotopic ratios of uranium and plutonium for these three enrichments are compared with the measured ratios in the reactor sump in Table 7.30 The measured ratios compare favorably with the average isotopic ratios for the $1.98 \%$ and $2.64 \% 235 \mathrm{U}$-enriched fuel and the core average ratios. From this comparison, it was concluded by $D$. A. Powers ${ }^{30}$ that the central region of the core containing the two lowest ${ }^{235} \mathrm{U}$ enrichments was certainly damaged, and that the observed ratios were generally indicative of a core uniformly damaged across its cross section. However, a cursory review of the data in Table 7 would suggest that the measured isotopic ratios are in better agreement with the core average ratios, indicating uniform damage.

\subsection{Fuel Temperatures}

Estimates of the fuel temperatures can be made based on the types of isotopes released and on their release fractions. Isotopes can be grouped as a function of their volatility as shown in Table 8, a synthesis of tables in References 37 and 32 . Under normal operation, the noble gases and halogens are released from the fuel matrix to the fuel-cladding gap. At higher temperatures, such as those that might be sustained under accident conditions, isotopes of progressively lower volatility are released. The longer the fuel remains at high temperature, the greater is the release fraction of that isotope.

Isotopic release fractions are summarized in Table 9. All of the data shown represent a nearly complete accounting of the radioisotope inventory following August 28, 1979 when a sample of the containment building sump was obtained. In general, about 60 to $70 \%$ of the noble gases, and $50 \%$ to $60 \%$ of the iodines and cesiums were released to the coolant. The increase in the strontium release fraction from March to August is consistent with its leaching rate from fuel exposed to water. Under the conditions that were calculated for TMI-2, the NRC Special Inquiry Group cautiously concluded that between $40 \%$ and $60 \%$ of the core inventory of 
TABLE 7. COMPARISON OF CALCULATED AND OBSERVED ISOTOPIC RATIOS OF URANIUM AND PLUTONIUM 30

\begin{tabular}{|c|c|c|c|c|c|c|}
\hline \multirow[b]{2}{*}{ Species } & \multicolumn{6}{|c|}{ Amount $(\%)$ of Isotope Relative to Total Elemental Abundance in: } \\
\hline & $\begin{array}{l}1.98 \% \\
\text { Enriched Fuel }\end{array}$ & $\begin{array}{l}2.64 \% \\
\text { Enriched Fuel }\end{array}$ & $\begin{array}{l}2.95 \% \\
\text { Enriched Fuel }\end{array}$ & $\begin{array}{l}\text { Observed } \\
\text { in Sump }\end{array}$ & $\begin{array}{l}\text { Average of } \\
1.98 \text { and } 2.64 \% \\
\text { Enriched Fuel }\end{array}$ & Core Average \\
\hline $\begin{array}{l}235 u \\
236 u \\
238 u\end{array}$ & $\begin{array}{l}1.605 \\
0.074 \\
98.32\end{array}$ & $\begin{array}{r}2.254 \\
0.081 \\
97.665\end{array}$ & $\begin{array}{r}2.572 \\
0.083 \\
97.345\end{array}$ & $\begin{array}{l}2.207 \\
0.064 \\
97.71\end{array}$ & $\begin{array}{l}1.943 \\
0.078 \\
97.98\end{array}$ & $\begin{array}{r}2.156 \\
0.080 \\
97.763\end{array}$ \\
\hline $\begin{array}{l}239 \mathrm{pu} \\
240 \mathrm{pu} \\
241 \mathrm{pu}\end{array}$ & $\begin{array}{r}87.916 \\
9.684 \\
2.292\end{array}$ & $\begin{array}{c}90.274 \\
7.97 \\
1.697\end{array}$ & $\begin{array}{r}91.098 \\
7.341 \\
1.497\end{array}$ & $\begin{array}{r}90.6 \\
7.84 \\
1.46\end{array}$ & $\begin{array}{c}89.145^{\mathrm{a}} \\
8.790 \\
1.982\end{array}$ & $\begin{array}{r}89.807 \\
8.299 \\
1.818\end{array}$ \\
\hline
\end{tabular}

a. The original table in Reference 30 had 87.145 , a typographical error. 
TABLE 8. VOLATILITY GROUPINGS OF FISSION PRODUCT ISOTOPESA

\begin{tabular}{|c|c|c|c|c|c|}
\hline \multirow[b]{2}{*}{ Group } & \multirow[b]{2}{*}{ Classification } & \multirow[b]{2}{*}{ Volatility } & \multirow[b]{2}{*}{ I sotopes } & \multicolumn{2}{|c|}{ Range of Boiling Points } \\
\hline & & & & $(K)$ & $\left({ }^{\circ} \mathrm{F}\right)$ \\
\hline I & Noble gases & High & $\mathrm{Kr}, \mathrm{Xe}$ & 120 to 165 & $(-243$ to -162$)$ \\
\hline I I & Halogens & High & $\mathrm{Br}, \mathrm{I}$ & 332 to 456 & $(138$ to 361$)$ \\
\hline III & Alkali metals & Intermediate & $\mathrm{Cs}, \mathrm{Rb}$ & 958 to 973 & (1265 to 1292$)$ \\
\hline IV & Tellurium & Intermediate & & 1260 & $(1809)$ \\
\hline V & $\begin{array}{l}\text { Alkaline } \\
\text { earths }\end{array}$ & Low & $\mathrm{Sr}, \mathrm{Ba}$ & 1639 to 1908 & (2491 to 2975) \\
\hline VI & Noble metals & $\begin{array}{l}\text { Volatile } \\
\text { under } \\
\text { highly } \\
\text { oxidizing } \\
\text { conditions }\end{array}$ & $\begin{array}{l}\mathrm{Ru}, \mathrm{Rh}, \\
\mathrm{Pd}, \mathrm{Tc}, \\
\mathrm{Mo}\end{array}$ & 2475 to 5073 & (3996 to 8672 ) \\
\hline VII & $\begin{array}{l}\text { Rare earths, } \\
\text { actinides }\end{array}$ & Low & $\mathrm{Sm}, \mathrm{Ce}, \mathrm{La}$ & 1875 to 3750 & (2916 to 6290$)$ \\
\hline VIII & $\begin{array}{l}\text { Refractory } \\
\text { oxides }\end{array}$ & Low & $\mathrm{Zr}, \mathrm{Nb}$ & 4600 to 5200 & $(7820$ to 8900$)$ \\
\hline
\end{tabular}

a. From References 31 and 32 . 


\section{TABLE 9. SUMMARY OF FISSION PRODUCT RELEASE FRACTIONS}

\begin{tabular}{|c|c|c|c|c|c|}
\hline \multirow[b]{3}{*}{ Isotope } & \multicolumn{5}{|c|}{ Release Fraction (x) } \\
\hline & \multirow{2}{*}{$\begin{array}{l}\text { March 28, } 1979 \\
\text { Reference } 22 \\
\end{array}$} & \multicolumn{3}{|c|}{ August 28,1979} & \multirow[b]{2}{*}{ Average } \\
\hline & & Reference 33 & Reference 4 & Reference 23 & \\
\hline $85 k r$ & 71.0 & $60.0^{\mathrm{a}}$ & -- & -- & 65 \\
\hline $137 m \times e$ & 70.0 & $60.0^{a}$ & -- & -- & 65 \\
\hline $133 x e$ & 68.0 & $60.0^{a}$ & 46 & $57^{b}-60^{c}$ & 58 \\
\hline $131_{I}$ & $59.0^{d, e}$ & $29.0^{f}$ & 399 & -- & $56^{\mathrm{h}}$ \\
\hline${ }^{134} \mathrm{Cs}$ & 76.0 & 39.0 & 44 & -- & 53 \\
\hline $136 c_{5}$ & $57.0^{\mathrm{e}}$ & $\cdots$ & $\cdots$ & - & 57 \\
\hline${ }^{137} \mathrm{Cs}$ & 60.0 & 49.0 & 63 & -- & 57 \\
\hline${ }^{89} \mathrm{Sr}$ & $<0.01$ & 1.5 & -- & -- & $\mathbf{i}$ \\
\hline $90 s r$ & $<0.07$ & 1.7 & -- & -- & $\mathbf{i}$ \\
\hline
\end{tabular}

a. Reference refers to noble gas release fraction of $60 \%$ without distinguishing between $\mathrm{Kr}$ and $\mathrm{Xe}$.

b. P. Cohen, "Fission Product Release from the Core, Three Mile Island-2," July 20, 1979 (see Reference 23).

c. H. R. Denton, Letter from NRC to V. L. Johnson, Director, Technical Staff, President's Commission on the Accident at Three Mile Island, September 28, 1979 (see Reference 23).

d. The release fractions of $131_{I}, 136 \mathrm{Cs}$, and $137 \mathrm{Cs}$ should be quite close since reactor coolant samples showed that the fractions of the core inventory of these nuclides in the coolant were close 10.124 , 0.120 , and 0.126 , respectively); therefore, the release fractions of $131_{I}$ and $136 \mathrm{Cs}$ were estimated by multiplying the $137 \mathrm{Cs}$ release fraction by the ratio of the fractions in the reactor coolant.

e. The iodine release based on literal acceptance of the gnalytial results is $42 \%$, but based on its chemical behavior and fission product release experiments, 34 the iodine release fraction should be close to the cesium release fraction.

$f$. The iodine and cesium release fractions are expected to be similar; thus, it is anticipated that about another $20 \%$ of the iodine will be found in the reactor purification demineralizer, deposited on reactor control rod material (silver), or plated on the reactor containment cooling coils (copper).

g. This work is considered to be about $20 \%$ too low as noted in Footnote $f$.

h. Average includes an additional 20\% above the August 28, 1979 measurement as noted in Footnotes $f$ and $g$.

i. Amount released from March 28 to August 28, 1979 is consistent with leaching rate from fuel exposed to water. 
Groups I, II, and III in Table 8 was released to the coolant. 4 A small amount of Group IV and a minute amount of the remaining groups were released. The average values shown in Table 9 would tend to support the nigher end of this range.

A variety of conclusions regarding fuel temperatures can be drawn from these data. Based on analyses of the water sample March 29, 1979, BAPL 35 concluded that: (a) most of the volatile fission products were released to the coolant; and (b) 2 to $12 \%$ of the fuel reached 1900 to $2500 \mathrm{~K}$ $\left(2960\right.$ to $4040^{\circ} \mathrm{F}$ ). From the air sample on March 31, 1979, BAPL 35 concluded that: (a) the cladding of about $90 \%$ of the 36816 fuel rods ruptured; and (b) about $30 \%$ of the fuel exceeded $2200 \mathrm{~K}\left(3500^{\circ} \mathrm{F}\right)$.

Considering only the ${ }^{133}$ Xe release fraction of $57 \%,{ }^{36}$ the technical staff of the President's Commission speculated on the fuel temperatures. $^{13,23}$ Lorenz $^{37}$ stated that over a period of a few hours, very little of the fission gas would be expected to be released from fuel at temperatures up to $1875 \mathrm{~K}\left(2915^{\circ} \mathrm{F}\right)$. During the thermal transient between 101 and 210 minutes after the turbine tripped, perhaps the lower one-quarter of the fuel rods remained covered with water. Near the water/steam interface the rods were cooled by steam. Thus, the staff considered that about one-third of the rod length remained cool enough to retain the fission gas within the fuel matrix. A ${ }^{133}$ xe release fraction of $57 \%$ from the whole core implies that $85 \%$ must be released from the upper two-thirds of the core. Lorenz ${ }^{37}$ stated that a fuel temperature of 2675 to $2775 \mathrm{~K}\left(4355\right.$ to $\left.4535^{\circ} \mathrm{F}\right)$ would be required. On the basis of these considerations, the staff concluded that $50 \%^{23}$ to $66 \%^{13}$ of the core exc eeded temperatures of $2475 \mathrm{~K}\left(3995^{\circ} \mathrm{F}\right)$, and that more than $90 \%$ of the fuel rods ruptured. 23 The number of cladding ruptures is consistent witn BAPL's analyses, but the fuel rod temperatures are somewhat nigher.

A substantially different estimate of the fuel rod temperatures has been obtained by J. Rest and C. E. Johnson. 38 Their analysis of essentially the same fission product release data described above indicates that most of the severely damaged regions of the core remained below $2000 \mathrm{~K}$ $\left(3140^{\circ} \mathrm{F}\right) .4,22,33$ 


\subsection{Fuel Melting}

By the time fuel rod temperatures achieved high enough values to cause liquefaction or fuel melting, many fission products would have volatilized and diffused out of the fuel. Upon liquefaction or melting, other fission products, such as tellurium and ruthenium, may be released. Many factors control the release of Te and Ru, which may also occur prior to fuel melting. So, although the presence of Te and $R u$ does not always mean that melting has occurred, their absence generally means that melting has not occurred.

Two primary coolant samples taken on March 28 and Apri1 10, 1979 showed very little strontium, ruthenium, and tellurium. ${ }^{4} \mathrm{~A}$ sample of the reactor sump was also taken on August 28, 1979. Analysis of the Sr content indicated that approximately $2 \%$ of the $S r$ inventory in the fuel had been released. In addition, about $0.02 \%$ of the core inventory of $129 \mathrm{~m}_{\mathrm{Te}}$ was found. Based on the low release fractions of strontium, tellurium, and ruthenium, it was concluded that "no significant quantity of the fuel reached the melting point of $\mathrm{UO}_{2} \cdot{ }^{\prime 4}$ There is general agreement on this aspect of the accident.

\subsection{Particle Size Distribution}

Estimates of the fuel particle size were obtained by considering the leaching rate of refractory elements from the fuel during the period between March 29 and April 10, 1979. As shown in Table 5, the concentrations of strontium and barium in the coolant were very small on March 2y, but had increased to an average of about $1 \%$ and $0.1 \%$, respectively, by April 10. Research has shown that the leaching rates are comparable to those from glass. 39,40

A definitive calculation of the particle size distribution in TMI-2 is not possible, however, several estimates have been made. 4,30,41 It was generally concluded that a large portion of the core was fragmented and 
that the size of the particles was probably on the order of a few millimeters rather than dustlike. Powers 30 stated that particles equivalent to a sphere having a radius of less than $0.3 \mathrm{~mm}$ would be leviated by the coolant flow and would have escaped the reactur coolant system to a much greater extent than the remaining particles of larger radii.

Figure 5 illustrates particle size distributions which have been observed in a variety of tests, both in-pile and out-of-pile. The RIA $1-1^{42}$ and PCM-1 20 in-pile tests had oxidized cladding which was fragmented to varying degrees. Preliminary data from out-of-pile tests were provided by the Waste Forms Response Project, that is developing fundamental information on particle size distributions in irradiated and unirradiated commercial fuel subjected to high impact loading. This work, performed by EG\&G Idaho, Inc., supports Sandia National Laboratories Transportation Technology Center's studies of spent commercial fuel shipping casks. TMI-2 may have a particle size distribution representative of the data shown in Figure 5 . 


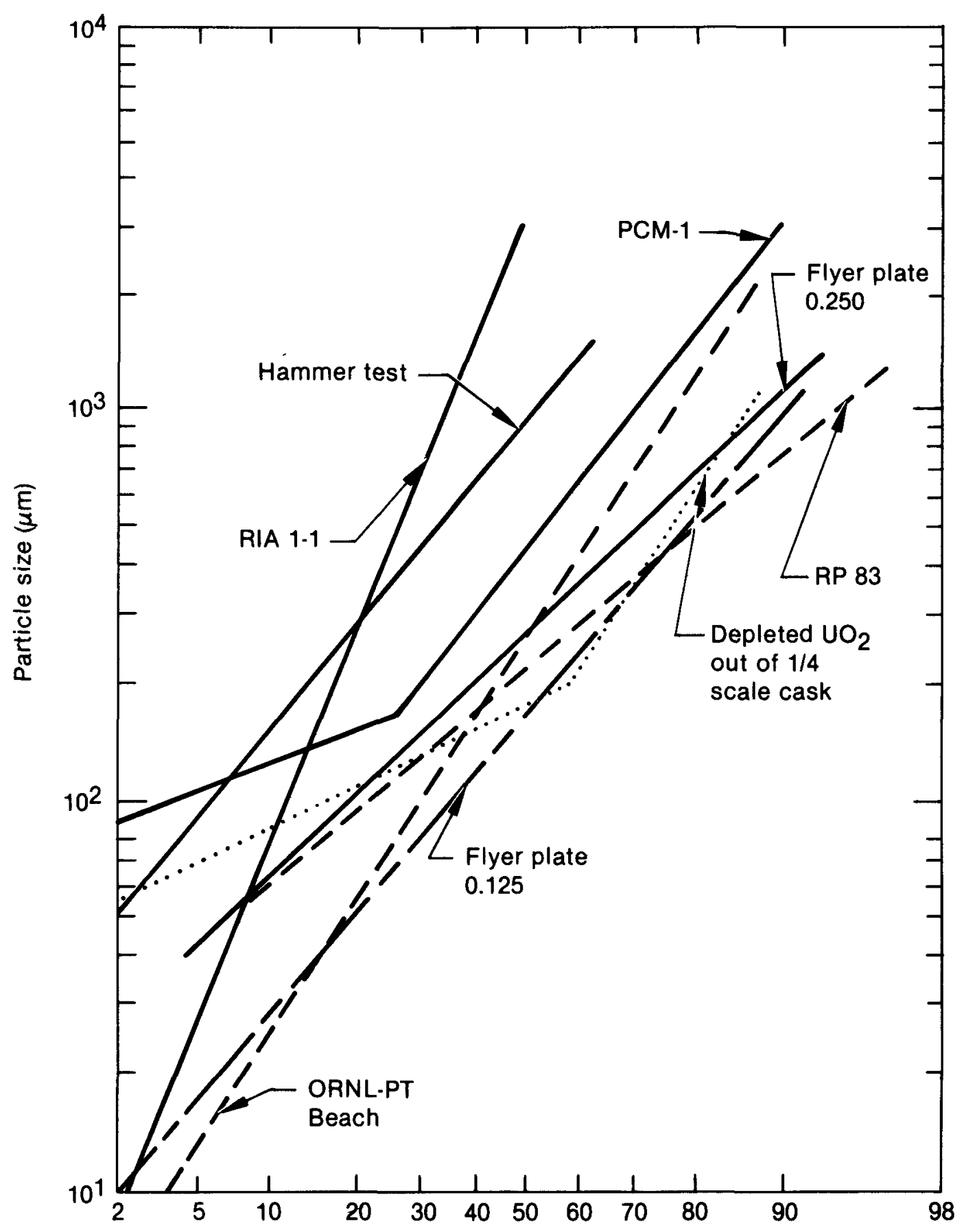

Particles that are of a size equal to or less than indicated value (wt\%) INEL-A-16 966

Figure 5. Particle size distributions from several types of tests. 


\section{CONCLUSIONS REGARDING TMI-2 CORE STATUS}

Estimates of the core damage based on the interpretation of the thermal-hydraulic events, hydrogen generation, and fission product release have been reviewed. This section will summarize the limits of core damage and describe a "reference" core for the purpose of developing tooling and procedures for reactor disassembly, defueling, core inspection, and fuel sample acquisition. However, as a contingency, tooling should be available to encompass the minimum, reference, and maximum limits of core damage.

\subsection{Damage Limits and Reference Core}

Table 10 summarizes the damage limits estimated by various investigators and discussed previously. The estimates for each item in the table may not be self-consistent for the minimum and maximum estimates of damage since the estimates have been made by a variety of individuals. The "reference" core is also defined in the table and is self-consistent, lying between the minimum and maximum damage estimates.

Figures 6,7 , and 8 illustrate the minimum damage estimate, the reference core, and the maximum damage estimate, respectively. In constructing the figures, consideration was given to the following parameters: (a) the number of failed rods and the condition of the peripheral rods; (b) the estimated core blockage area; (c) the percent of cladding oxidized in the active core region; and (d) the embrittlement level in the core, based on the estimated minimum water-steam mixture level during the accident. Appendix $D$ discusses the method of constructing the figures in greater detail. Three regions of cladding oxidation are snown as a function of the fractional height and radius of the active fuel region of the TMI-2 core. The height, Ho, and the equivalent radius, Ro, are equal to $3.66 \mathrm{~m}(12 \mathrm{ft})$ and $1.64 \mathrm{~m}(5.4 \mathrm{ft})$, respectively. A region of cladding immediately above the mixture level was assumed to be below the $17 \%$ embrittlement criterion and thus intact. Farther above the mixture level, a region of the cladding is expected to be embrittled, that is, 


\begin{tabular}{|c|c|c|c|}
\hline & Minimum & Reference & Maximum \\
\hline Failed Rods (\%) & $>90$ & 2100 & 100 \\
\hline Fuel temperature $(\mathrm{K})$ & $\begin{array}{l}\text { Gross average } \\
\text { in damaged region } \\
<2000\end{array}$ & $\begin{array}{l}\text { Peak } \\
22600\end{array}$ & $\begin{array}{l}\text { Peak } \\
22900\end{array}$ \\
\hline $\begin{array}{l}\text { Cladding oxidized in } \\
\text { active fuel region }(\%)\end{array}$ & 40 & 50 & 60 \\
\hline Liquified fuel & Locally possible & $\begin{array}{l}\text { Present in } \\
\text { several areas } \\
\text { of central } \\
\text { core }\end{array}$ & $\begin{array}{l}\text { Present over } \\
\text { most of core } \\
\text { radius, perhaps } \\
\text { extending down- } \\
\text { ward to } \omega \mathrm{m} \\
\text { above core } \\
\text { bottom. }\end{array}$ \\
\hline Molten fuel & None & None & $\begin{array}{l}\text { Possible in a } \\
\text { few localized } \\
\text { areas of cen- } \\
\text { tral core }\end{array}$ \\
\hline Core slumping & Probable & Yes & Yes \\
\hline $\begin{array}{l}\text { Fuel rod fragmentation, } \\
\text { debris bed formation }\end{array}$ & Yes & Yes & Yes \\
\hline Peripheral rods & $\begin{array}{l}\text { A few not } \\
\text { breached, some } \\
\text { embrittled }\end{array}$ & $\begin{array}{l}\text { Few, if any } \\
\text { not breached, } \\
\text { most embritti- } \\
\text { ed near top of } \\
\text { core }\end{array}$ & $\begin{array}{l}\text { All failed and } \\
\text { embrittled, } \\
\text { many with } \\
\text { liauified fuel }\end{array}$ \\
\hline $\begin{array}{l}\text { Control rods and spacer } \\
\text { grids }\end{array}$ & Molten & Melted & Melted \\
\hline Instrument tubes & Most intact & $\begin{array}{l}\text { Most in cen- } \\
\text { tral region } \\
\text { failed, peri- } \\
\text { pheral tubes } \\
\text { intact }\end{array}$ & All faiied \\
\hline $\begin{array}{l}\text { Embrittlement } \\
\text { level ( } m \text { above bottom } \\
\text { of core at centerline) }\end{array}$ & 1.8 & 1.4 & 0.9 \\
\hline Upper plenum assemblies & $\begin{array}{l}\text { No distortion, } \\
\text { melting or fusing } \\
\text { to other stainless } \\
\text { steel components }\end{array}$ & $\begin{array}{l}\text { Some } \\
\text { distortion and } \\
\text { local melting } \\
\text { possible. May } \\
\text { be fused to } \\
\text { upper end } \\
\text { fittings }\end{array}$ & $\begin{array}{l}\text { Melting over } \\
\text { the central } \\
\text { lower region. } \\
\text { Major slumping } \\
\text { possible }\end{array}$ \\
\hline
\end{tabular}




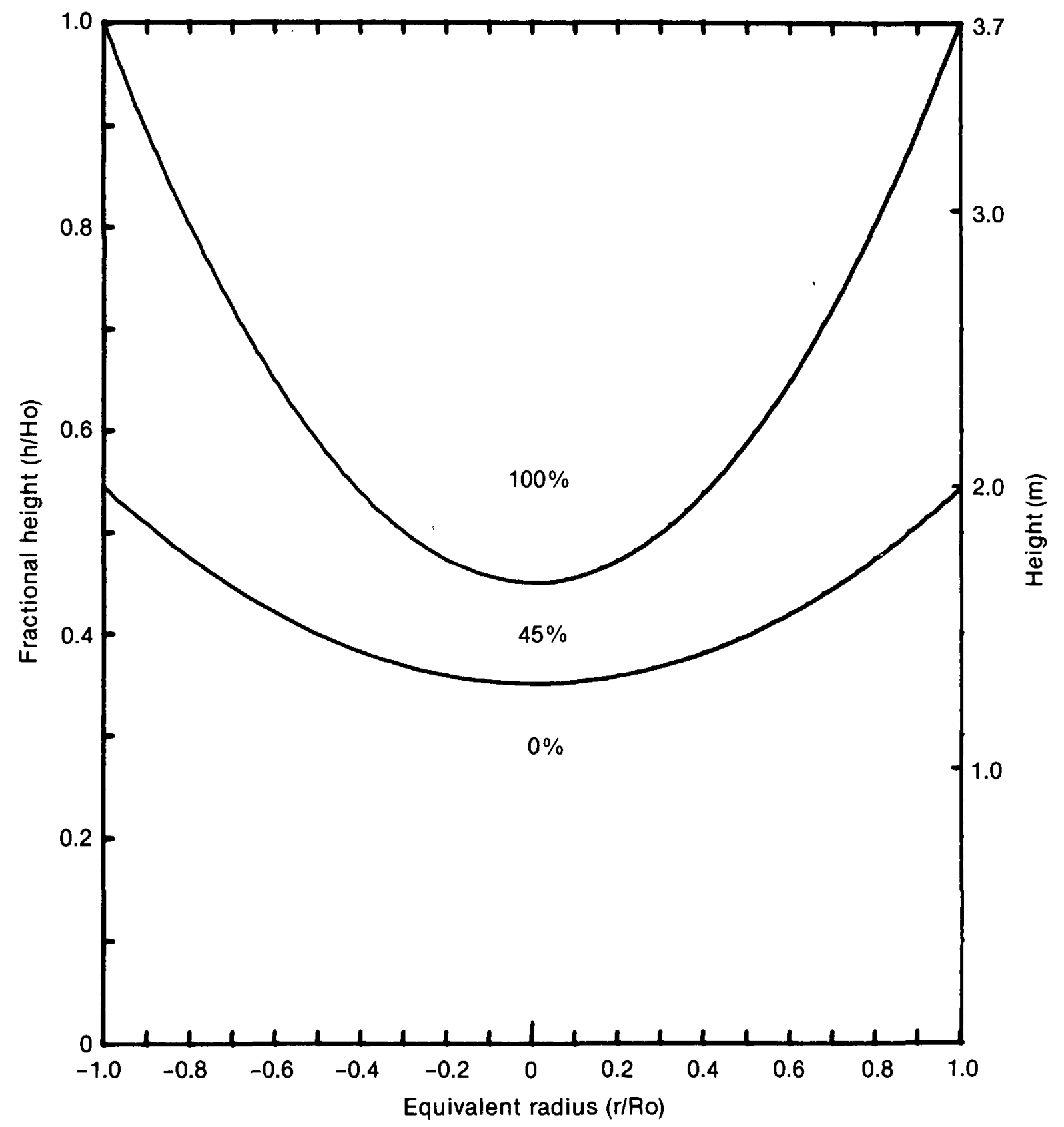

Figure 6. Regional average oxidation and estimated minimum damage configuration of the TMI-2 core. 


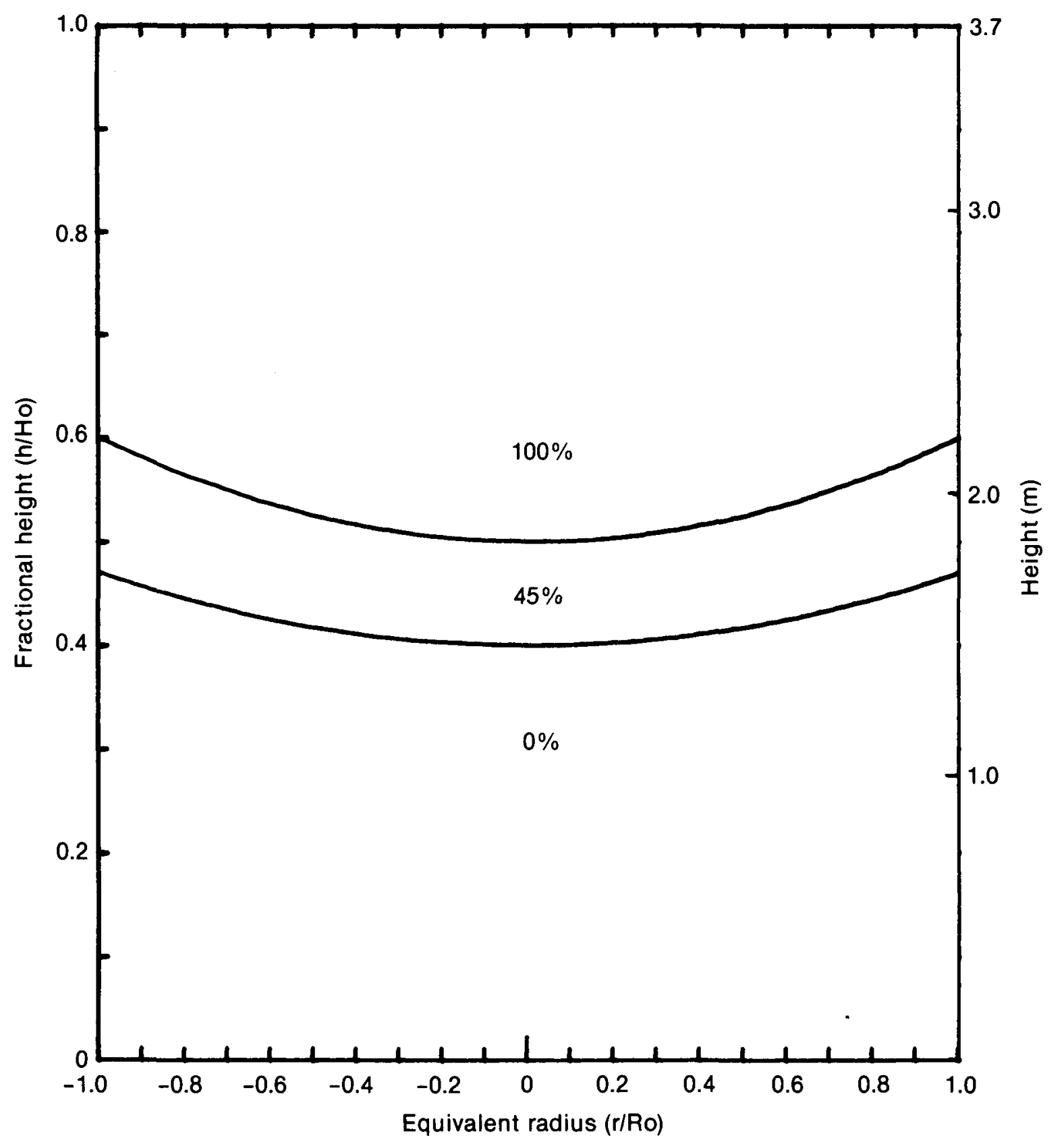

Figure 7. Regional average oxidation and reference configuration of the TMI-2 core. 


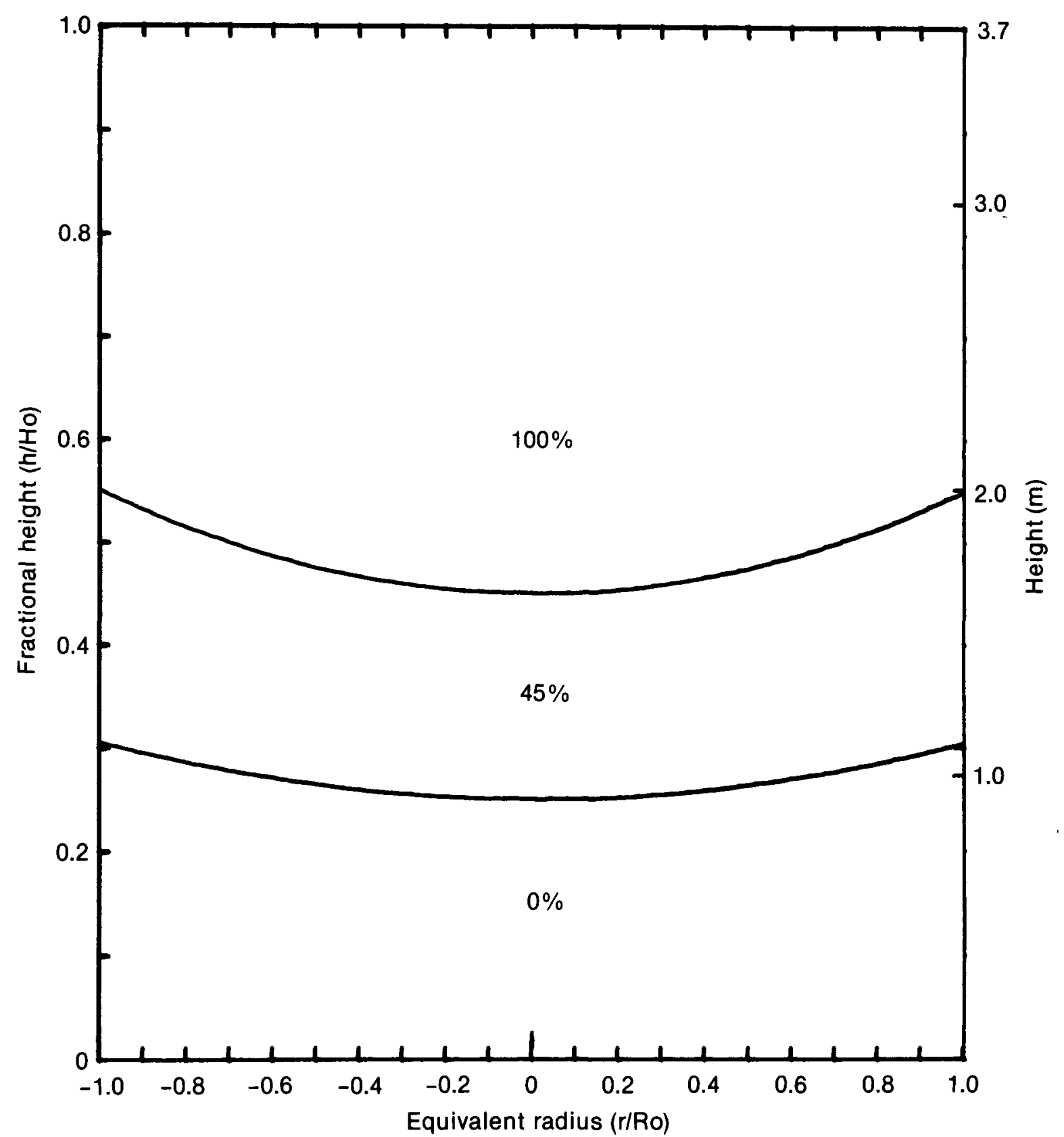

Figure 8. Regional average oxidation and estimated maximum damage configuration of the TMI-2 core. 
greater than the $17 \%$ embrittlement criterion, but not fully oxidized. For this region, an average oxidation of $45 \%$ of the cladding was assumed. From this region to the top of the active core, $100 \%$ oxidation was assumed.

The minimum damage estimate illustrated in Figure 6 was based on $40 \%$ cladding oxidation, and partially embrittled peripheral rods. Although the minimum coolant mixture level was estimated to be $1.8 \mathrm{~m}(5.9 \mathrm{ft})$, this criterion cannot be met without either reducing the amount of cladding oxidation or allowing the damage to be more uniformly distributed across the core. Based on the core flow area blockage measurements discussed in Section 2.2 and the isotopic ratios of uranium and plutonium found in the reactor building sump mentioned in Section 4.1 , the core damage is expected to be more uniform.

Figure 7 illustrates the reference core. Embrittlement of the peripheral rods, $50 \%$ cladding oxidation, and minimum embrittlement level of $1.4 \mathrm{~m}(4.6 \mathrm{ft})$ was assumed. The maximum damage estimate is illustrated by Figure 8 in which fairly uniform damage, $60 \%$ oxidation, and a minimum embrittlement level of $1.1 \mathrm{~m}(3.6 \mathrm{ft})$ was considered.

As evidenced by the highly qualitative discussion in Section 2.2 regarding estimated plenum temperatures, few definitive comments can be made regarding the condition of the plenum. If the calculated temperatures on which the damage estimates were based are actually lower, the upper plenum may remain fully intact. However, melted control rod guide tude brazements, and partially molten or fused stainless steel components would characterize an estimate of maximum damage to the upper plenum structures. For instance, fuel assembly upper end fittings could be fused to the upper core support plate and control rod spiders could be fused to their male coupling pins. It is also likely that some components may rest on top of the core debris. 


\subsection{Tooling Development for Defueling}

There are several primary core damage parameters that will affect the development of tooling for reactor disassembly and defueling. They are: a) the condition of the upper plenum assembly; (b) the extent of cladding embrittlement, (c) the presence of previously liquified or molten materials; and (d) the condition of the instrument and guide tubes. This section concentrates on these four parameters.

As a contingency, tooling and procedures capable of handling the estimated maximum amount of damage to the upper plenum assembly components should be developed. In the event that normal control rod disconnect procedures are unsuccessful at all positions, tooling and techniques must be developed to remove the remaining control rod drive mechanisins or to sever the leadscrews either above or below the reactor vessel head. The vessel head should be removed without significant problems. Techniques for identifying and separating fused fuel assembly upper end fittings from the upper core support plate should be devised. As a last resort, major cutting may be required.

As a result of the significant cladding oxidation and fuel rod fragmentation which occurred in the TMI-2 core, investigators have suggested that a debris bed is being supported by portions of rods which are embrittled to varying degrees. The upper portion of these rod stubs may be brittle enough to fracture while the debris bed above them is being disturbed or removed, perhaps by the use of a vacuum technique. Once the bed is removed, attempts to handle them during core defueling are expected to fragment the rods further.

Based on the assessments reviewed in Section 2, the presence of previously liquified or molten material cannot be discounted. Because of this, contingency tooling should be developed. The minimum damage estimates state that localized areas of liquified fuel are possible. In the worst case, liquified fuel is expected to be present over most of the 
core radius, perhaps extending downward to approximately $1 \mathrm{~m}$ (approximately $3 \mathrm{ft}$ ) above the bottom of the core. In essentially all of the damage assessments, the $\mathrm{UO}_{2}$ fuel is not expected to have become molten during the course of the accident. Nonfuel core components such as unoxidized zircaloy cladding, spacer grids, stainless steel cladding, and the control rod poison material are expected to have melted over large regions of the core. The once-liquid material may span a height of $2 \mathrm{~m}(6.5 \mathrm{ft})$. Cementation of the debris into larger masses by these materials will probably necessitate the use of saws or other cutting tools to separate fuel assemblies or reduce the size of debris masses before removal and packaging.

Since damage to the instrument and guide tubes also cannot be discounted, contingency tooling should be developed for removing fuel assemblies having severely damaged tubes. For those assemblies that have intact, structuraliy sound tubes and upper end fittings, normal or slightiy modified procedures could be used for fuel assembly removal. For assemblies having failed tubes, whose upper portions are embrittled, the tubes may still be used for withdrawing the assembly once the debris is removed. A tool, perhaps an expanding mandrel, could be inserted into the tube down to a location below the embrittled region, however, the presence of cemented debris may preclude insertion of such a tool. Alternatively, a can with grappling fingers at the bottom could lift the assembly from the bottom.

Table 11 summarizes the types of materials expected to be present in the TMI-2 core.

\subsection{Conclusions}

The minimum and maximum bounds of damage have been identified and a reference description of the TMI-2 core has been defined. These damage limits have been established by reviewing core damage assessments based on reconstruction of the thermal-hydraulic events, determinations of the 
TABLE 11. SUMMARY OF POTENTIAL RANGE OF CORE CONDITIONS TO BE USED IN PLANNING OF CONTINGENCY TOOLING

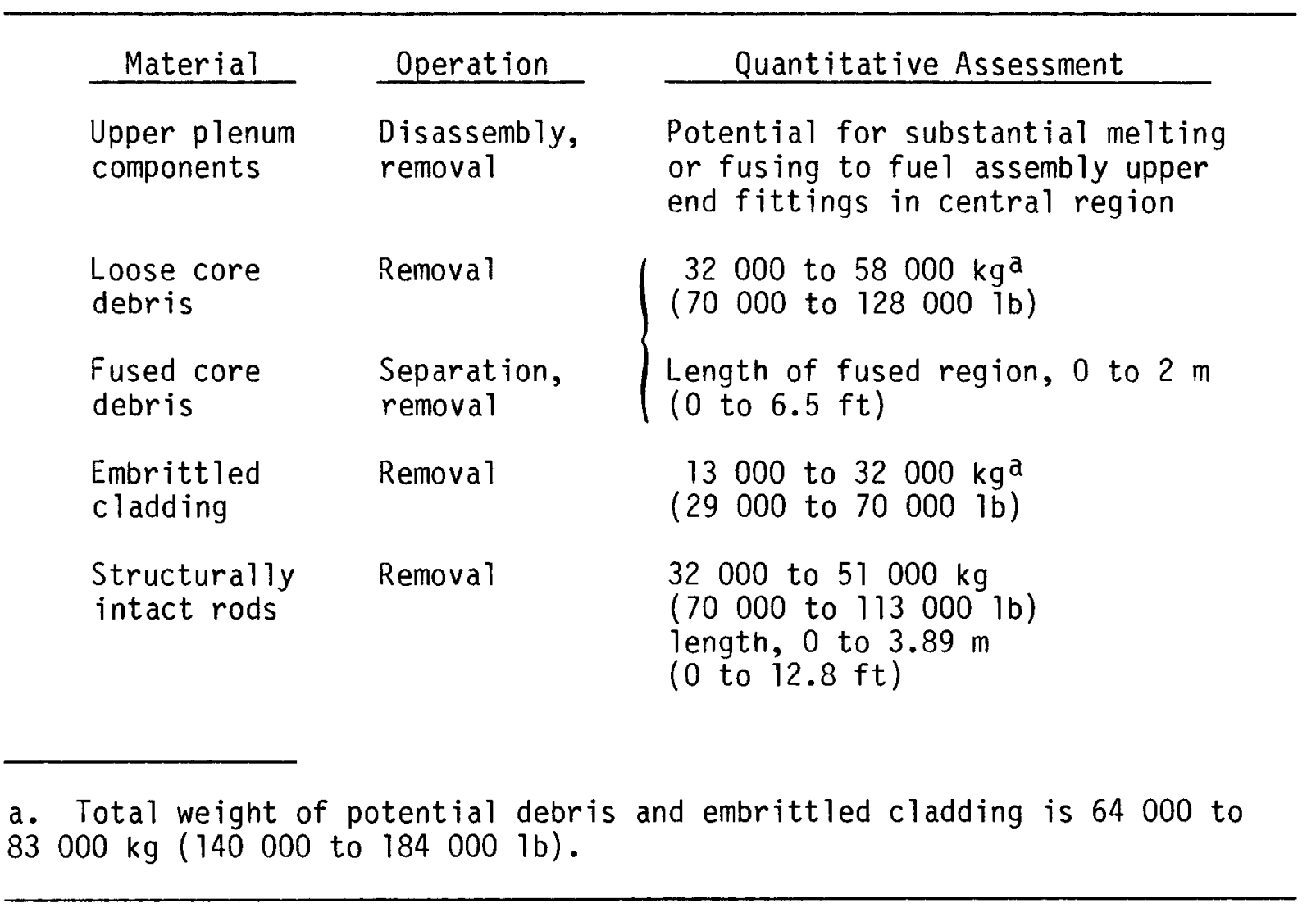


hydrogen generated, and fission product release data. The information contained in Figures 6,7 , and 8 and in Tables 10 and 11 should be considered in planning contingency tooling and procedures for reactor disassembly, defueling, core inspection, and fuel sample acquisition. 


\section{REFERENCES}

1. GEND Planning Report, GEND-001, October 1980, Chapters 7.2 and 7.4 .

2. K. H. Ardron and.D. G. Cain, "Modelling of the Liquid Level During Uncovering of the TMI-2 Core," ANS/ENS Topical Meeting on Thermal Reactor Safety, Knoxville, Tennessee, April 6-9, 1980, CONF-800403, June 1980, pp. 597-613.

3. EPRI, Analysis of Three Mile Island - Unit 2 Accident, NSAC-80-1, March T980, App. CI.

4. M. Rogovin, Three Mile Island--A Report to the Commissioners and to the Public, US NRC Special Inquiry Group, NUREG/CR-1250, Vol. II, Part 2, January 1980, Section C.2, pp 487-550.

5. J. R. Ireland, "Three Mile Island System Thermal-Hydraulic Analys is Using TRAC," ANS/ENS Topical Meeting on Thermal Reactor Safety, Knoxville, Tennessee, April 6-9, 1980, CONF-800403, June 1980, pp.574-581.

6. R. 0. Wooten, R. S. Denning, P. Cybulskis, Analys is of the Three Mile Island Accident and Alternative Sequences, NUREG/CR-1219, January 1980.

7. D. L. Burman, et al., "Degraded Core Cooling Calculations for TMI- 2 ," Transactions American Nuclear Society, 34, June 1980, pp. 869-870.

8. R. E. English, "Thermal-Hydraulics," Reports of the Technical Assessment Task Force to the President's Commission on the Accident at Three Mile Island, Vol. II, October 1979.

9. M. Rogovin, Three Mile Island--A Report to the Commissioners and to the Public, US NRC Special Inquiry Group, NUREG/CR-1250, Vol. II, Part 2, January 1980, Appendix II.8, pp. 741-755.

10. EPRI, Analysis of the Three Mile Island Unit 2 Accident, NSAC-1, July 1979.

11. P. Griffith and N. Todreas, "Review of Thermal-Hydraulic Events at TMI-2," August 16, 1979 (see also Reference 7).

12. W. L. Kirchner, J. R. Ireland, and P. K. Mast, "Fuel Damage Estimates for the TMI-2 Reactor, "ANS/ENS Topical Meeting on Thermal Reactor Safety, Knoxville, Tennessee, April 6-9, 1980, CONF-800403, June 1980, pp. 590-596.

13. R. E. English, "Core Damage," Reports of the Technical Assessment Task Force to the President's Commission on the Accident at Three Mile IsTand, Vol. II, October 1979. 
14. G. R. Thomas, "Significant Aspects of TMI-2 Core Damage and Material Performance," CSNI Specialist Meeting on Safety Aspects of Fuel Behavior in off-Normal and Accident Conditions, Espoo, FinTand, September 1-4, 1980.

15. S. Hagen and H. Malauschek, "Bundle Experiments on the Meltdown Behavior of PWR Fuel Rods," Trans. Am. Nucl. Soc., Vol. 33,

November 1979, pp. 505-506.

10. NRC, Evaluation of Long-Term Post-Accident Core Cooling of Three Mile Is land, Unit 2, NUREG-0557, May 1979, Appendix A.

17. M. Rogovin, Three Mi le Island--A Report to the Commissioners and to the Public, USNRC Special Inquiry Group, NUREG/CR-1250, Vol. II, Part 2, January 1980, Section C.2, p. 512.

18. Hollen Warren, Babcock \& Wilcox, Private communication, October 29, 1980.

19. W. Bixby et al., "Three Mile Island Core Integrity Assessment," Industry Advisory Group, April 13, 1979 (NSAC File No. IAG-TA-0004).

20. B. A. Cook, Fuel Rod Material Behavior During Test PCM-1, NUREG/CR-0757, TREE-1333, June 1979.

21. EPRI, Analysis of Three Mile Island - Unit 2 Accident, NSAC-80-1, March 1980, App. HYD.

22. W. N. Bishop et al., "Fission Product Release From the Fuel Following the TMI-2 Accident," ANS/ENS Topical Meeting on Thermal Reactor Safety, Knoxville, Tennessee, Aprif 6-9, 1980, CoNF-800403, June 1y80, pp. 622-629.

23. R. E. English, "Chemistry," Reports of the Technical Assessment Task Force to the President's Commission on the Accident at Three Mile Island, VoT. II, October 1979 .

24. Metropolitan Edison Company, "Preliminary Annotated Sequence of Events, March 31, 1979 through Apri1 30, 1979," July 20, 1979.

25. A. D. Miller, Nuclear Safety Analysis Center, Private communication, October 16, 1980.

26. P. K. Mast, T. R. Wehner, and J. R. Ireland, "Analys is of Early Core Damage at Three Mile Island," ANS/ENS Topical Meeting on Thermal Reactor Safety, Knoxville, Tennessee, April 6-9, 1980, CoNF-800403, June 1980, pp. 582-589.

27. J. R. Ireland, "TRAC Analysis of Three Mile Island Accident," Trans. Am. Nucl. Soc., Vol. 34, June 1980, pp. 501-503. 
28. T. England and W. Wilson, TMI-2 Decay Power: LASL Fission Product and Actinide Decay Power CalcuTations for the President's Commission on the Accident at Three Mile Island, LA-804T-MS, 1979.

29. F. Miraglia, "Letter from NRC to R. English, Staff of President's Commission on TMI-2," July 5, 1979 (see also Ref. 21).

30. M. Rogovin, Three Mile Island--A Report to the Commissioners and to the Public, US NRC Special Inquiry Group, NUREG/CR-1250, Vol. II, Part 2, January 1980, Section C.2, pp. 803-805.

31. USNRC, Reactor Safety Study--An Assessment of Accident Risks in U. S. Commercial Nuclear Power Plants, WASH-1400, NUREG 75/014, October 1975, Appendix VII.

32. G. W. Parker and C. J. Barton, "Fission-Product Release," The Technology of Nuclear Reactor Safety, Vo1. 2, T. J. Thompson and J. G. Beckerley, eds., The M.I.T. Press, Cambridge, Massachusetts, 1973, pp. 525-618.

33. A. D. Miller, "Radiation Source Terms and Shielding at TMI-2," Transactions of the American Nuclear Society, 34, June 1980, pp. 633-635.

34. USNRC Reactor Safety Study - An Assessment of Accident Risks in U. S. Commercial Nuclear Power PTants, WASH-1400, NUREG 75/014, October 1975, Appendix VII pp. 11-12 and Appendix D (August 1974).

35. Anonymous, Preliminary Anotated Sequence of Events, March 29, $197 y$ through Apriा 30, 19/9, Metropotitan Edison Co., July 20 19/9 (see also Reference 21).

36. P. Cohen, "Fission Product Release from the Core, Three Mile Island-2," July 20, 1979 (see also Refs. 12 and 21).

37. R. A. Lorenz, Letter from Oak Ridge National Laboratory to R. English, Staff of President's Commission on TMI-2, August 14, 1979.

38. J. Rest and C. E. Johnson, A Prediction of TMI-2 Core Temperatures from the Fission Product Re Tease History, NSAC-12 (ANL/LWR/SAF 80-3), November 1980.

39. Y. B. Katayama and J. E. Mande1, "Leaching of Irradiated LWR Fue I Pellets in Deionized Water, Sea Brine, and Typical Groundwater," Transactions of the American Nuclear Society, 27, November-December 1977, pp. 477-478.

40. Y. B. Katayama, Leaching of Irradiated Fuel Pellets in Deionized and Typical Groundwater, BNWL-2057, JuTy 1976. 
41. M. Rogovin, Three Mile Island--A Report to the Commissioners and to the Public, USNRC Special Inquiry Group, NUREG CR/-1250, Vol. II, Part 2, January 1980, Append ix II.7, pp. 737-739.

42. S. L. Seiffert, Z. R. Martinson, and S. K. Fukuda, Reactivity Initiated Accident Test Series, Test RIA 1-1 (RadiaT Average Fuel Enthalpy of $285 \mathrm{cal} / \mathrm{g}$ ), Fuel Behavior Report, NUREG/CR-1465, EGG-2040, September 1980. 
APPENDIX A

TMI-2 CORE DESIGN PARAMETERS 
-

- 
TABLE A-1. FUEL ASSEMBLY COMPONENTS, MATERIALS AND DIMENSIONS ${ }^{A-1}$

\begin{tabular}{|c|c|c|}
\hline Item & Material & Dimensions, in. \\
\hline \multicolumn{3}{|l|}{ Fuel Rod (208 rods/assy) } \\
\hline Fuel & $\begin{array}{l}\mathrm{U}_{2} \text { disn-end, sintered } \\
\text { pe } 1 \text { lets ( } 92.5 \% \text { TD), } 2.57 \\
\text { wt\% } 235 \mathrm{U} \text { (core average, } \\
\text { first cycle) }\end{array}$ & 0.370 diameter \\
\hline Cladding & Zircaloy -4 & $\begin{array}{l}0.43000 \times 0.377 \text { ID } \\
\times 153.125 \text { long }\end{array}$ \\
\hline Fuel rod pitch & -- & 0.568 \\
\hline Active fuel length & -- & 144 \\
\hline $\begin{array}{l}\text { Nom. fuel-cladding } \\
\text { gap }(B O L)^{a}\end{array}$ & -- & 0.007 \\
\hline Ceramic spacer & $\mathrm{ZrO}_{2}$ & $0.3660 D$ \\
\hline \multicolumn{3}{|l|}{ Fuel Assembly } \\
\hline Number Pitch & -- & $\begin{array}{l}177 \\
8.587\end{array}$ \\
\hline Overall length & -- & 165.625 \\
\hline $\begin{array}{l}\text { Control rod guide tubes } \\
\text { (16) }\end{array}$ & Zircaloy-4 & $0.53000 \times 0.498 \mathrm{ID}$ \\
\hline Instrument tube (1) & Zircaloy -4 & $0.4930 D \times 0.441 \mathrm{ID}$ \\
\hline End fittings (2) & 304 SS (castings) & -- \\
\hline Spacer grids (8) & Incone 1-718 & -- \\
\hline Spacer sleeves (7) & Zircaloy -4 & $0.55400 \times 0.502 \mathrm{ID}$ \\
\hline
\end{tabular}


TABLE A-2. CONTROL ROD ASSEMBLY DATAA-1

\begin{tabular}{|c|c|}
\hline I tem & Data \\
\hline $\begin{array}{l}\text { Number of full-length CRAs } \\
\text { Number of control rods per assembly } \\
\text { Outside diameter of control rod, mm (in.) } \\
\text { Cladding thickness, mm (in.) } \\
\text { Cladding material } \\
\text { End plug material } \\
\text { Spider material } \\
\text { Poison material } \\
\text { Female coupling material } \\
\text { Length of poison section, m(in.) } \\
\text { Stroke of control rod, } m(\text { in.) }\end{array}$ & $\begin{array}{l}61 \\
16 \\
11.18(0.440) \\
0.533(0.021) \\
304 \mathrm{SS}, \text { cold-worked } \\
304 \mathrm{SS}, \text { annealed } \\
\text { SS grade CF-3M } \\
80 \% \mathrm{Ag}, 15 \% \text { In, } 5 \% \mathrm{Cd} \\
304 \mathrm{SS}, \text { annealed } \\
3.40(134) \\
3.53(139)\end{array}$ \\
\hline
\end{tabular}

TABLE A-3. AXIAL POWER SHAPING ROD ASSEMBLY DATA A-1

\begin{tabular}{lc}
\hline \multicolumn{1}{c}{ Item } & \multicolumn{1}{c}{ Data } \\
\cline { 2 - 2 } Number of APSRAs & 8 \\
Number of APSR/assy & 16 \\
Outside diameter of APSR, mm (in.) & $11.18(0.440)$ \\
Cladding thickness, mm (in.) & $0.533(0.021)$ \\
Cladding material & $304 \mathrm{SS}$, cold-worked \\
Plug material & $304 \mathrm{SS}$, annealed \\
Poison material & $80 \% \mathrm{Ag}, 15 \%$ In, $5 \% \mathrm{Cd}$ \\
Spider material & $\mathrm{SS}$ grade CF-3M \\
Female coupling material & $304 \mathrm{SS}$, annealed \\
Length of poison section, m (in.) & $0.91(36)$ \\
Stroke of APSR, m (in.) & $3.53(139)$ \\
\end{tabular}


TABLE A-4. BURNABLE POISON ROD ASSEMBLY DATA ${ }^{A-1}$

\section{Item}

Number BPRAs

Number of burnable poison rods per assembly

Outside diameter of burnable poison rod, mm (in.)

Cladding thickness, mm (in.)

Cladding material

End cap material

Poison material

Length of poison section, m (in.)

Spider material

Coupling mechanism material
Data

68

16

$10.92(0.430)$

$0.889(0.035)$

Zircaloy-4, cold-worked

Zircaloy -4 , annealed

$\mathrm{Al}_{2} \mathrm{O}_{3}-\mathrm{B}_{4} \mathrm{C}$

$3.20(126)$

SS, grade CF-3M

304SS, annealed and

17-4PH, condition H1100

TABLE A-5. ORIFICE ROD ASSEMBLY DATA ${ }^{A-1}$

\section{I tem}

Number of orifice rod assemblies

Number of orifice rods per assembly

Outside diameter of or ifice rod, mm (in.)

Orifice rod material

Spider material

Coupling mechanism material
Data

97

16

$12.19(0.480)$

304 SS, annealed

$\mathrm{SS}$, grade $\mathrm{CF}-3 \mathrm{M}$

304 SS, annealed, and

17-4 PH, condition H1100 
TABLE A-6. CORE DESIGN DATAA-1

A. Reactor

1. Design neat output (MWt)

2772

2. Vessel coolant in let temperature, $K$ (OF)

$565(557)$

3. Vessel coolant outlet temperature $K$ ( OF)

$592.8(607.7)$

4. Core coolant outlet temperature $K$ (OF)

$594.4(610.6)$

5. Core operating pressure, MPag (psig)

$15.1(2185)$

B. Core and Fuel Assemblies

1. Total fuel assemblies in core

2. Fuel rods per fuel assembly

208

3. Control rod guide tubes per assembly

16

4. In-core instr. positions per fuel assembly

C. Fuel Assembly Volume Fractions

Fuel

0.303

Moderator

0.580

Zircaloy

0.102

Stainless steel

0.003

Void

$\underline{0.012}$

1.000

D. Total UO 2 Beginning of Life

$\mathrm{UO}_{2}$, first core (metric tons)

93.1

E. Core Dimensions

Equivalent diameter, m (in.)

$3.27(128.9)$

Active height, m (in.)

$3.66(144.0)$ 
TABLE A-7. MELTING POINTS OF CORE MATERIALSA-2

\section{Material}

$\mathrm{UO}_{2}$

Zircaloy -4 (Fuel Rod Cladding and Guide Tubes)

$\mathrm{ZrO}_{2}$ (By-Product Metal-Water Reaction)

Inconel 718 (Spacer Grid) 1559

Ag-In-Cd (Control Rod Poison)

304 SS (Cladding of Control Rods and Axial Power Shape Rods)

SS, grade CF-3M

$\mathrm{Al}_{2} \mathrm{O}_{3}-\mathrm{B}_{4} \mathrm{C}$ (Axial Power Shape Rods)

$\mathrm{UO}_{2}-\mathrm{Gd}_{2} \mathrm{O}_{3}$ ( 2 fuel assemblies contained gadolinia test rods)
Melting Temperature

(K)

$\overline{3078}$

$\left({ }^{0} \mathrm{~F}\right)$

2123

3362

2988

4919

$1533-$

1559

$2300-$

2346

1060

1472

$1672-$

1694

2550-

2590

1698

2600

2303

3686

3023

4982 


\section{REFERENCES}

A-1. Metropolitan Edison Co. et al., Three Mile Island Nuclear Station, Unit 2, Final Safety Analys is Report, DOCKET-50320-73, April 4, 1974, Chapter 4.

A-2. NRC, Evaluation of Long-Term Post-Accident Core Cooling of Three Mile Is land, Unit 2, NUREG-0557, May 1979, Append ix A.

A-3. Metals Handbook, Ninth Edition, Metals Park, Onio: American Society For Metals, 1980, Volume Three, Properties and Selection: Stainless Steels, Tool Materials, and Special Purpose Metals. 
APPENDIX B

ZIRCALOY OXIDATION 
○. 
APPENDIX B

ZIRCALOY OXIDATION

0xidation of zirconium in steam proceeds according to the exothermic reaction

$2 \mathrm{H}_{2} \mathrm{O}+\mathrm{Zr} \rightarrow \mathrm{ZrO}_{2}+2 \mathrm{H}_{2} \uparrow$

such that two moles of hydrogen are produced for every mole of zirconium consumed to become zirconium dioxide. Based on the calculated mass of hydrogen produced, the amount of zirconium oxidized can be calculated as follows:

$\operatorname{Zr}(\mathrm{kg})=\frac{\mathrm{H}(\mathrm{kg})}{2 \mathrm{kgH} / \mathrm{mole}_{2}} \times \frac{1 \text { mole } \mathrm{Zr}}{2 \text { moles } \mathrm{H}_{2}} \times \frac{91.22 \mathrm{~kg} \mathrm{Zr}}{1 \text { mole } \mathrm{Zr}}$

$\operatorname{Zr}(\mathrm{kg})=22.805 \times \mathrm{H}(\mathrm{kg})$

Since zircaloy (Zry) is $98 \%$ zirconium, ${ }^{B-1}$ the amount of zirconium oxidized for each kilogram of hydrogen produced is

$\operatorname{Zry}(\mathrm{kg})=\operatorname{Zr}(\mathrm{kg}) / 0.98=23.27 \mathrm{H}(\mathrm{kg})$.

This equation was used to obtain the values in Table 3 of cladding oxidized. Dividing the amount of zircaloy oxidized by the amount of zircaloy in the core, $23920 \mathrm{~kg},{ }^{B-2}$ from Appendix $C$, yields the fraction of zircaloy oxidized.

\section{REFERENCES}

B-1. P. D. Kaufmann and E. F. Baroch, "Potential for Improvement of Mechanical Properties in Zircaloy Cold-Rolled Strip and Sheet," Zirconium in Nuclear Applications, ASTM STP 551, American Society for Testing and Materials, 1974, pp. 129-139. 
B-2. Letter, R. N. Duncan, Combustion Engineering, Inc., to E. L. Zebroski, EPRI, "Utility/Industry Committee on Reactor Core Condition, TMI-2 Zircaloy Inventory," FMD-79-140, Apri1 17, 1979. 
APPENDIX C

ZIRCALOY INVENTORY AND DISTRIBUTION IN TMI - 2 


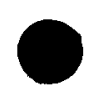




\section{APPENDIX C}

\section{ZIRCALOY INVENTORY AND DISTRIBUTION IN TMI-2}

From Reference $\mathrm{C}-1$, the preaccident zircaloy inventory in the core of 177 assemblies is distributed as follows:

Component

Fuel rod cladding

Upper and lower end plugs

Spacer discs (inside fuel rod near top)

Assembly guide tubes

Instrument tubes

Burnable poison cladding

TOTAL

\begin{tabular}{|c|c|}
\hline \multicolumn{2}{|c|}{ Mass } \\
\hline $\mathrm{kg}$ & $1 \mathrm{bm}$ \\
\hline 20411 & 45000 \\
\hline 635 & 1400 \\
\hline 318 & 700 \\
\hline 1678 & 3700 \\
\hline 318 & 700 \\
\hline 502 & 1240 \\
\hline 23922 & 52740 \\
\hline
\end{tabular}

The fuel rod cladding, assembly guide tubes, and instrument tubes are $3.89 \mathrm{~m}$ (153.125 in.) long; the fueled length of the rods is $3.66 \mathrm{~m}$ (144 in.). Thus, the amount of zircaloy in the active region of the core is the ratio of the lengths multiplied by the weight of those three components and added to the weight of the burnable poison cladding. The end plugs and spacer discs are considered to be out of the core.

Performing the calculation yields a value of $21634 \mathrm{~kg}$ (47 $703 \mathrm{lbm})$ for the weight of zircaloy in the active region of the core. This is $90.4 \%$ of the total amount of zircaloy in the core.

\section{REFERENCE}

C-1. Letter, R. N. Duncan, Combustion Engineering, Inc., to E. L. Zebroski, EPRI, "Utility Industry Committee on Reactor Core Condition, TMI-2 Zircaloy Inventory," FMD-79-140, April 17, 1979, (NSAC File No. ANA-CO-0015). 
APPENDIX 0

CONSTRUCTION OF CORE DAMAGE LIMIT ILLUSTRATIONS 
0

0 


\section{APPENDIX D \\ CONSTRUCTION OF CORE DAMAGE LIMIT ILLUSTRATIONS}

This appendix briefly outlines the manner in which Figures 6,7 , and 8 , illustrating the minimum, reference, and maximum damage estimates, were constructed.

Four assumptions were common to all the damage estimates. First, a general parabolic shape was chosen for the interface between aifferent oxidation regions of the core. Second, three types of regions were assumed to exist: (a) cladding in the upper elevations was assumed to be $100 \%$ oxidized; (b) cladding in the central elevations was expected to be embitted (greater than $17 \%$ oxidized), but less than $100 \%$ oxidized due to uncovery during only part of the accident, so $45 \%$ was chosen; and (c) cladding in the lower regions was not uncovered, remaining below the $17 \%$ embrittlement criterion, so $0 \%$ was chosen. The volume of each region was obtained by integrating the parabolic equation as a solid of revolution about the core centerline. Multiplying the regional volumes by the fractional amount of oxidation within each region yielded the total amount of zircaloy oxidation in the active core region.

Third, it was assumed that the minimum water-steam mixture level controlled the elevation of the zircaloy embrittlement, namely, the location of the boundary between the bottom and central regions of oxidation. Lastly, the estimate of $90 \%$ blockage tended to indicate that even the peripheral fuel assemblies were damaged to some extent.

In obtaining Figure 6 , the minimum damage estimate, it was specifically assumed that some of the peripheral rods were intact. oxidation of $100 \%$ was chosen to extend across the whole core diameter, but only to a very small depth at the edges of the core. In the remaining estimates, fairly uniform damage was assumed. 


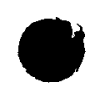

: 
-

1 
0

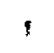

